\title{
Influence of catchment quality and altitude on the water and sediment composition of 68 small lakes in Central Europe
}

\author{
Beat Müller ${ }^{1}$, André F. Lotter ${ }^{2,3}$, Michael Sturm ${ }^{3}$ and Adrian Ammann ${ }^{3}$ \\ 1 Swiss Federal Institute of Environmental Science and Technology (EAWAG), \\ Limnological Research Center, CH-6047 Kastanienbaum, Switzerland \\ 2 University of Berne, Geobotanical Institute, Altenbergrain 21, CH-3013 Bern, Switzerland \\ 3 Swiss Federal Institute of Environmental Science and Technology (EAWAG), \\ CH-8600 Dübendorf, Switzerland
}

Key words: Lakes, catchment, land use, climate, nitrogen, phosphate.

\begin{abstract}
68 lakes (63 Swiss, 2 French and 3 Italian) located in an altitudinal range between 334 and $2339 \mathrm{~m}$ spanning a wide range of land-use have been investigated. The aim of the study was to discuss influences of geographic location, vegetation and land-use in the catchment area on the water and sediment chemistry of small lakes. Detailed quantitative description of land-use, vegetation, and climate in the watershed of all lakes was established. Surface and bottom water samples collected from each lake were analyzed for major ions and nutrients. Correlations were interpreted using linear regression analysis. Chemical parameters of water and sediment reflect the characteristics of the catchment areas. All lakes were alkaline since they were situated on calcareous bedrock. Concentrations of nitrogen and phosphorus strongly increase with increasing agricultural land-use. $\mathrm{Na}$ and $\mathrm{K}$, however, are positively correlated with the amount of urbanization within the catchment area. These elements as well as dissolved organic carbon (DOC), $\mathrm{Mg}, \mathrm{Ca}$, and alkalinity, increase when the catchment is urbanized or used for agriculture. Total nitrogen and organic carbon in the sediments decrease distinctly if large parts of the catchment consist of bare land. No correlations between sediment composition and maximum water depth or altitude of the lakes were found.

Striking differences in the water compositions of lakes above and below approximately $700 \mathrm{~m}$ of altitude were observed. Concentrations of total nitrogen and nitrate, total phosphorus, DOC, $\mathrm{Na}, \mathrm{K}, \mathrm{Mg}, \mathrm{Ca}$, and alkalinity are distinctly higher in most lakes below $700 \mathrm{~m}$ than above, and the $\mathrm{pH}$ of the bottom waters of these lakes is generally lower. Estimates of total nitrogen concentrations, even in remote areas, indicate that precipitation is responsible for increased background concentrations. At lower altitudes nitrogen concentrations in lakes is explained by the nitrogen loaded rain from urban areas deposited on the catchment, and with high percentages of agricultural land-use in the watershed.
\end{abstract}

\section{Introduction}

The water composition of a lake as well as its sedimentary record are influenced by factors such as climate, geology, vegetation, and land-use in the catchment area 
(e.g., Margalef, 1994). This close catchment and lake relationship renders the aquatic ecosystem sensitive to environmental changes (e.g., Schindler, 1987; Psenner and Schmidt, 1992; Larsen et al., 1996). A major issue is to understand the relevant processes that operate between catchment and lake as well as to recognize traces imprinted by prevailing environmental conditions. Spatial and temporal scale are of high importance for both factors. Knowledge of past lake development can only be gained by understanding the key processes of how environmental signals are archived via the water column into the sediment (e.g., Anderson and Battarbee, 1994). Therefore, investigations of the present-day situation in different lakes along environmental gradients (e.g., climate, trophic state, see Pienitz and Smol, 1993; Brenner and Binford, 1988) may help to better understand past lake development and thus assess the long term development of lacustrine ecosystems.

Sixty eight small lakes of comparable size situated along a climate and trophic gradient were sampled to assess the potential of different aquatic organisms (e.g., diatoms, cladocera, chironomids, chrysophytes) as quantitative indicators of past environmental change (Lotter et al., 1997a, b). Watershed-lake interaction can be studied easier with small lakes since specific influences are more apparent. Uniform catchments and short hydraulic residence times render small lakes more sensitive to influences of their water and sediment quality than large lakes. Specific chemical characteristics of anthropogenically influenced parameters are expressed more pronounced and can be traced and assigned easier. Analysis of the chemical data contributes to the characterisation of watershed-lake interactions and reveals distribution patterns of nutrients in small lakes. Knowledge of the processes that lead to these patterns are of importance when investigating alpine river systems and controlling new legislations and methods in farming. This study also contributes to regional limnology since especially the small lakes studied here are limnologically not well-known compared to larger Swiss lakes.

Here, we investigate the chemical information from water and surface sediments in relation to landuse and altitude and discuss the susceptibilities and chemical response of the lakes to anthropogenic impact. All selected lakes lay in carbonaceous catchment areas and have high buffer capacities against acids (high alkalinity). Therefore, the impact of acid deposition in the watersheds and its impact on lake acidification is of negligible significance. We follow the plea of Livingstone and Imboden (1996) to test if our data corroborate major in-lake processes rather than to obtain overall statistical relationships to search for new mechanisms. Focus is on reflections of geographic location and catchment areas in the processes that cause the observed limnological situation.

\section{Methods}

Sites selected for this study include small lakes between 0.007 and $0.67 \mathrm{~km}^{2}$ situated in carbonate bedrock areas at elevations between 334 and $2339 \mathrm{~m}$. An overview of their geographic locations is given in Figure 1. Geographic data are presented in Table 1. Sampling was carried out during spring and autumn 1993 and spring 1994. Several echo-sounding tracks helped to locate the deepest part of each lake where a continuous temperature and conductivity profile was recorded using an OTS 


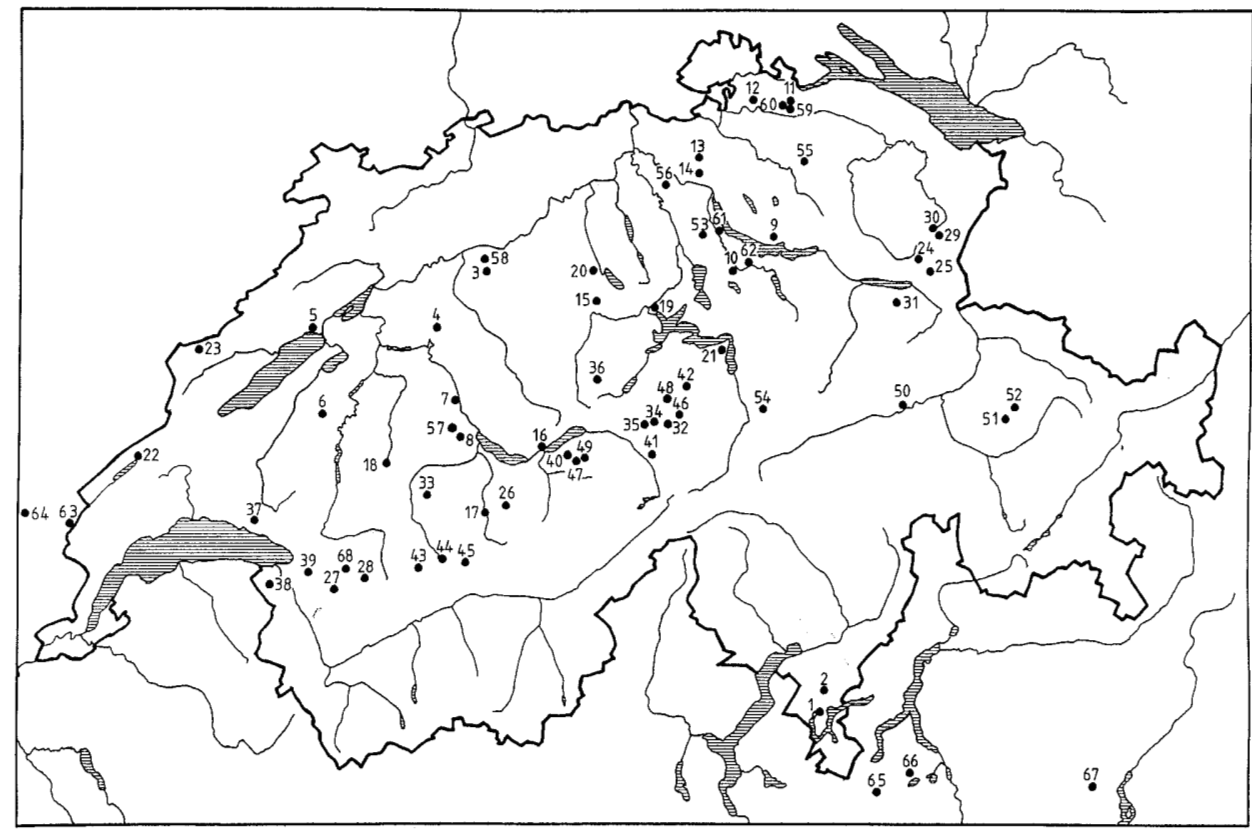

Figure 1. Map of Switzerland showing the geographic location of the 68 sampled lakes. Numbers refer to Table 1

probe (oxygen, temperature, conductivity; Meerestechnik GmbH, Trappenkamp, Germany). In thermally stratified lakes four samples were taken with a Niskin bottle $(20 \mathrm{~cm}$ depth, above and below the thermocline; $1 \mathrm{~m}$ above the sediment surface). In unstratified lakes only three water samples were taken (surface; mid water depth; $1 \mathrm{~m}$ above the sediment). Only data from surface and bottom samples have been used for overall comparisons.

Oxygen content was determined by the Winkler method. $\mathrm{pH}$ was measured in the field because $\mathrm{pH}$ values measured in the laboratory the day after sampling deviated markedly from the field measurements due to $\mathrm{CO}_{2}$ degassing. Alkalinity was determined by titration with strong acid to $\mathrm{pH}$ 4.3. DOC was measured by thermic oxidation with a Shimatsu TOC-500. Phosphate was determined photometrically with the molybdenum blue method (DEW 1996), nitrate with the salicylic acid method (DEW 1996), and silicate with the molybdosilicate method (DEW 1996). Total phosphorus (TP) and total nitrogen (TN) were determined in unfiltered samples by acidic digestion with $\mathrm{K}_{2} \mathrm{~S}_{2} \mathrm{O}_{8}$ in an autoclave for $2 \mathrm{~h}$ at $120^{\circ} \mathrm{C}$ prior to analysis. $\mathrm{Ca}, \mathrm{Mg}, \mathrm{K}$, and $\mathrm{Na}$ were determined with an inductively coupled plasma with optical emission spectroscopy (ICP-OES, Spectro Analytical Instruments). Chemical speciations were calculated with the program ChemEQL (Müller, 1995). Data for soluble reactive phosphorus (SRP) were collected either by additional sampling during the circulation period or obtained from the cantonal water protection authorities. These data were used to classify the lakes into the four categories of trophic states according to the OECD (1982) recommendation (see Table 1): 
Table 1. Major hydrographical and limnological characteristics of the investigated 68 lakes. Numbers refer to Fig. 1. Trophic state is defined according to OECD (1982)

\begin{tabular}{|c|c|c|c|c|c|c|c|c|c|}
\hline abbrev. & no. & lake & $\begin{array}{l}\text { altitude } \\
{[\mathrm{m}]}\end{array}$ & $\begin{array}{l}\text { surf. } \\
\text { area } \\
{\left[\mathrm{km}^{2}\right]}\end{array}$ & $\begin{array}{l}\text { catchment } \\
\text { area } \\
{\left[\mathrm{km}^{2}\right]}\end{array}$ & $\begin{array}{l}\max . \\
\text { depth } \\
{[\mathrm{m}]}\end{array}$ & $\begin{array}{l}\text { residence } \\
\text { time } \tau_{\mathrm{w}} \\
{[\mathrm{a}]}\end{array}$ & $\begin{array}{l}\text { trophic } \\
\text { state }\end{array}$ & $\begin{array}{l}\text { sampling } \\
\text { date }\end{array}$ \\
\hline $\mathrm{ABB}$ & 64 & Lac de l'Abbaye & 871 & 0.8 & 25.93 & 18 & n.a. & $\mathrm{m}$ & 19. Mai. 94 \\
\hline BAC & 47 & Bachsee & 2265 & 0.07 & 1.87 & 16 & 0.22 & $\mathrm{~m}$ & 11. Aug. 93 \\
\hline $\mathrm{BAN}$ & 42 & Bannalpsee & 1587 & 0.16 & 8.23 & 17 & 0.13 & $\mathrm{~m}$ & 20. Jul. 93 \\
\hline $\mathrm{BIC}$ & 55 & Bichelsee & 590 & 0.09 & 2.7 & 6.5 & 0.22 & $\mathrm{e}$ & 22. Sep. 93 \\
\hline BLA & 17 & Blausee & 887 & 0.01 & 0.09 & 10 & 0.34 & $\mathrm{~m}$ & 30. Mär. 93 \\
\hline BRE & 22 & Lac Brenet & 1002 & 0.63 & 2.85 & 17 & 1.60 & $\mathrm{~m}$ & 18. Mai. 93 \\
\hline BRT & 37 & Lac de Bret & 674 & 0.5 & 2.97 & 18 & n.a. & $\mathrm{e}$ & 29. Jun. 93 \\
\hline BUG & 16 & Burgseeli & 613 & 0.09 & 1.18 & 19 & 0.63 & $\mathrm{e}$ & 30. Mär. 93 \\
\hline BUR & 3 & Burgäschisee & 465 & 0.19 & 4.29 & 31 & 0.94 & $\mathrm{e}$ & 15. Mär. 93 \\
\hline $\mathrm{CHA}$ & 14 & Unterer Chatzensee & 439 & 0.19 & 1.29 & 7.8 & 0.94 & $\mathrm{e}$ & 24. Mär. 93 \\
\hline $\mathrm{CHV}$ & 27 & Lac des Chavonnes & 1690 & 0.05 & 0.74 & 29.5 & 0.93 & $\mathrm{~m}$ & 2. Jun. 93 \\
\hline DIT & 57 & Dittligsee & 652 & 0.07 & 3.13 & 16.5 & 0.25 & $\mathrm{e}$ & 18. Apr. 94 \\
\hline EGE & 56 & Egelsee & 667 & 0.02 & 0.29 & 10 & 1.54 & $\mathrm{~m}$ & 29. Sep. 93 \\
\hline END & 67 & Lago di Endine & 334 & 0.49 & 8.34 & 8 & n.a. & $\mathrm{m}$ & 27. Mai. 94 \\
\hline ENG & 32 & Engstlensee & 1850 & 0.45 & 7.4 & 49 & 0.84 & $\mathrm{~m}$ & 15. Jun. 93 \\
\hline FÄL & 29 & Fälensee & 1446 & 0.15 & 4.25 & 31 & 0.94 & $\mathrm{~m}$ & 7. Jun. 93 \\
\hline FLU & 44 & Flueseeli & 2045 & 0.04 & 0.79 & 8.5 & 0.17 & $\mathrm{~m}$ & 28. Jul. 93 \\
\hline GAW & 61 & Gattiker Waldweiher & 545 & 0.03 & 1.88 & 5.5 & 0.055 & $\mathrm{e}$ & 26. Apr. 94 \\
\hline GER & 7 & Gerzensee & 603 & 0.27 & 2.7 & 10 & 0.93 & $\mathrm{e}$ & 17. Mär. 93 \\
\hline GRD & 50 & Lag Grond & 1016 & 0.02 & 1.89 & 5 & 0.028 & $\mathrm{~m}$ & 7. Sep. 93 \\
\hline GRO & 31 & Grosssee & 1620 & 0.05 & 2.2 & 11.5 & n.a. & $\mathrm{m}$ & 8. Jun. 93 \\
\hline HAG & 49 & Hagelseewli & 2339 & 0.03 & 0.36 & 18.5 & 0.59 & $\mathrm{~m}$ & 18. Aug. 93 \\
\hline HAS & 59 & Hasensee & 434 & 0.11 & 2.52 & 5.5 & 0.32 & $\mathrm{e}$ & 25. Apr. 94 \\
\hline HÜN & 62 & Hüttnersee & 658 & 0.17 & 2.33 & 12 & 0.66 & $\mathrm{e}$ & 26. Apr. 94 \\
\hline HUS & 12 & Husemersee & 409 & 0.08 & 1.33 & 14 & n.a. & $\mathrm{e}$ & 23. Mär. 93 \\
\hline HÜT & 11 & Hüttwilersee & 434 & 0.35 & 3.71 & 15 & 1.93 & $\mathrm{e}$ & 23. Mär. 93 \\
\hline IFF & 43 & Iffigsee & 2065 & 0.1 & 4.61 & 30 & 0.27 & $\mathrm{~m}$ & 27. Jul. 93 \\
\hline INK & 58 & Inkwilersee & 461 & 0.12 & 2.13 & 4.6 & 0.18 & $\mathrm{~h}$ & 19. Apr. 94 \\
\hline LÄM & 45 & Lämmerensee & 2296 & 0.07 & 1.55 & 2.5 & 0.057 & $\mathrm{~m}$ & 28. Jul. 93 \\
\hline LIO & 68 & Lac Lioson & 1848 & 0.07 & 1.5 & 25 & n.a. & $\mathrm{o}$ & 10. Aug. 94 \\
\hline $\mathrm{LOC}$ & 5 & Le Loclat & 432 & 0.05 & 0.88 & 9.2 & 0.75 & $\mathrm{e}$ & 16. Mär. 93 \\
\hline LUT & 48 & Lutersee & 1702 & 0.02 & 0.59 & 4.5 & 0.050 & $\mathrm{~m}$ & 12. Aug. 93 \\
\hline
\end{tabular}




\begin{tabular}{|c|c|c|c|c|c|c|c|c|c|}
\hline LÜT & 9 & Lützelsee & 500 & 0.13 & 6.02 & 6 & 0.10 & $\mathrm{e}$ & 22. Mär. 93 \\
\hline MAU & 20 & Mauensee & 504 & 0.6 & 4.3 & 7 & 0.83 & $\mathrm{e}$ & 11. Mai. 93 \\
\hline MEL & 35 & Melchsee & 1891 & 0.49 & 5.92 & 15.5 & 0.60 & $\mathrm{~m}$ & 21. Jun. 93 \\
\hline MET & 13 & Mettmenhasler See & 418 & 0.03 & 0.5 & 12.5 & 0.62 & $\mathrm{e}$ & 24. Mär. 93 \\
\hline MON & 65 & Lago di Montorfano & 397 & 0.52 & 1.57 & 6.5 & n.a. & $\mathrm{m}$ & 26. Mai. 94 \\
\hline MOO & 4 & Moossee & 521 & 0.31 & 10.41 & 21 & 0.56 & $\mathrm{~m}$ & 15. Mär. 93 \\
\hline MUZ & 1 & Lago di Muzzano & 337 & 0.22 & 2.2 & 3.2 & 0.14 & $\mathrm{~h}$ & 3. Mär. 93 \\
\hline NER & 39 & Lac de Nervaux & 1493 & 0.01 & 0.92 & 10 & n.a. & $\mathrm{e}$ & 30. Jun. 93 \\
\hline NUS & 60 & Nussbaumersee & 434 & 0.25 & 5.87 & 8.2 & 0.47 & $\mathrm{~m}$ & 25. Apr. 94 \\
\hline $\mathrm{OBE}$ & 52 & Obersee & 1734 & 0.08 & 2.71 & 14.5 & 0.22 & $\mathrm{~m}$ & 8. Sep. 93 \\
\hline ORI & 2 & Lago d'Origlio & 416 & 0.07 & 1.19 & 6 & 0.15 & $\mathrm{~m}$ & 10. Mär. 93 \\
\hline RET & 28 & Lac Retaud & 1685 & 0.01 & 0.22 & 4.5 & 0.093 & $\mathrm{e}$ & 2. Jun. 93 \\
\hline ROT & 19 & Rotsee & 419 & 0.5 & 4.6 & 16 & 0.94 & $\mathrm{e}$ & 11. Mai. 93 \\
\hline $\mathrm{ROU}$ & 63 & Lac des Rousses & 1058 & 0.89 & 15.68 & 11.5 & 0.28 & $\mathrm{~m}$ & 18. Mai. 94 \\
\hline $\mathrm{SÄG}$ & 40 & Sägistalsee & 1935 & 0.07 & 3.85 & 9.7 & 0.080 & $\mathrm{~m}$ & 7. Jul. 93 \\
\hline SAL & 30 & Seealpsee & 1143 & 0.14 & 11.33 & 15 & 0.067 & $\mathrm{~m}$ & 8. Jun. 93 \\
\hline $\mathrm{SCE}$ & 51 & Schwellisee & 1933 & 0.03 & 9.58 & 12 & 0.019 & $\mathrm{~m}$ & 7. Sep. 93 \\
\hline $\mathrm{SCH}$ & 18 & Schwarzsee & 1046 & 0.46 & 19.7 & 9.5 & 0.13 & $\mathrm{~m}$ & 31. Mär. 93 \\
\hline SCW & 24 & Schwendisee & 1159 & 0.04 & 5.06 & 9.5 & 0.028 & $\mathrm{~m}$ & 24. Mai. 93 \\
\hline SEB & 33 & Seebergsee & 1831 & 0.06 & 0.23 & 15.5 & 2.39 & $\mathrm{~m}$ & 16. Jun. 93 \\
\hline SEE & 6 & Lac de Seedorf & 609 & 0.1 & 7.38 & 7.5 & 0.12 & $\mathrm{~h}$ & 16. Mär. 93 \\
\hline SEG & 66 & Lago del Segrino & 374 & 0.34 & 2.66 & 8.5 & n.a. & $\mathrm{m}$ & 26. Mai. 94 \\
\hline SEL & 21 & Seelisberg Seeli & 738 & 0.18 & 2.7 & 37.5 & 0.73 & $\mathrm{~m}$ & 12. Mai. 93 \\
\hline SEW & 36 & Sewenseeli & 1689 & 0.03 & 0.21 & 4.5 & 0.26 & $\mathrm{~m}$ & 28. Jun. 93 \\
\hline SOP & 15 & Soppensee & 596 & 0.23 & 1.59 & 26.5 & 3.24 & $\mathrm{e}$ & 29. Mär. 93 \\
\hline SWL & 54 & Seewli See & 2038 & 0.08 & 2.7 & 16 & 0.17 & $\mathrm{~m}$ & 18. Sep. 93 \\
\hline TAI & 23 & Lac des Tailleres & 1036 & 0.44 & 33.16 & 8.5 & 0.050 & $\mathrm{e}$ & 19. Mai. 93 \\
\hline TAN & 34 & Tannensee & 1976 & 0.34 & 1.12 & 16 & 2.26 & $\mathrm{~m}$ & 21. Jun. 93 \\
\hline TAY & 38 & Lac Tanay & 1408 & 0.18 & 7.93 & 31 & n.a. & $\mathrm{m}$ & 29. Jun. 93 \\
\hline TRÜ & 46 & Trüebsee & 1764 & 0.26 & 7.07 & 7 & 0.11 & $\mathrm{~m}$ & 29. Jul. 93 \\
\hline TSC & 26 & Tschingelsee & 1150 & 0.11 & 36.65 & 1.6 & 0.002 & $\mathrm{~m}$ & 1. Jun. 93 \\
\hline TÜR & 53 & Türlersee & 643 & 0.5 & 5.19 & 21 & 1.70 & $\mathrm{~m}$ & 14. Sep. 93 \\
\hline UEB & 8 & Uebeschisee & 641 & 0.15 & 2.16 & 14.5 & 0.71 & $\mathrm{e}$ & 17. Mär. 93 \\
\hline VOR & 25 & Voralpsee & 1123 & 0.15 & 13.52 & 3.3 & 0.013 & $\mathrm{~m}$ & 25. Mai. 93 \\
\hline WAN & 41 & Wannisbordsee & 2103 & 0.02 & 1.64 & 14 & 0.047 & $\mathrm{o}$ & 8. Jul. 93 \\
\hline WIL & 10 & Wilersee & 730 & 0.03 & 0.5 & 21 & 0.70 & $\mathrm{e}$ & 22. Mär. 93 \\
\hline
\end{tabular}

$\mathrm{o}=$ oligotrophic $(<10 \mu \mathrm{gP} / \mathrm{L}) ; \mathrm{m}=$ mesotrophic $(10-35 \mu \mathrm{gP} / \mathrm{L})$; e=eutrophic $(35-100 \mu \mathrm{gP} / \mathrm{L}) ; \mathrm{h}=$ hypertrophic $(>100 \mu \mathrm{gP} / \mathrm{L})$. (n.a.: data were not available from hydrological atlas) 
oligotrophic $(<10 \mu \mathrm{gP} / \mathrm{L})$, mesotrophic $(10-35 \mu \mathrm{gP} / \mathrm{L})$, eutrophic $(35-100 \mu \mathrm{gP} / \mathrm{L})$, hypertrophic $(>100 \mu \mathrm{gP} / \mathrm{L})$. In all figures, specific markers have been used for oligotrophic (triangles), mesotrophic (circles), eutrophic (diamonds), and hypertrophic lakes (squares).

Sediment cores were obtained from the deepest location of the lakes with a gravity corer. The cores were extruded on site and the uppermost $5 \mathrm{~cm}$ sampled in $1 \mathrm{~cm}$ sections. The samples were freeze-dried, pulverized, and digested with $4 \mathrm{ml}$ of concentrated $\mathrm{HNO}_{3}$ and $1 \mathrm{ml} \mathrm{H}_{2} \mathrm{O}_{2}$ in a microwave oven.

The relations between watershed descriptors, geographic and chemical information were ascertained using a Pearson correlation matrix with Bonferroniadjusted probabilities (Wilkinson, 1988) of the dataset.

\section{Results}

Geographical data and sampling data for all 68 lakes are listed in Table 1, and their locations are depicted in Figure 1. Chemical data for water analysis, sediments, and land use are given in appendices I-III. The $\mathrm{pH}$ values of surface waters ranged from 7.8 to 9 , alkalinity from 1 to $5 \mathrm{meq} / \mathrm{L}$, and calcium from 0.5 to $3 \mathrm{mM}$. Conductivity measurements $\left(\kappa\right.$, in $\left.\mu \mathrm{S} \mathrm{cm}^{-1}\right)$ are highly correlated with alkalinity (Alk, meq/L), suggesting that bicarbonate is the major anion in the investigated lakes, determining the ionic strength. The relationship obeys the following equation

$$
\kappa=0.22+0.0095 \cdot \mathrm{Alk}
$$

with a correlation coefficient $r=0.987(n=66)$.

$\mathrm{pH}$ values are generally higher in surface waters than in bottom waters in all lakes. Ca, alkalinity, TN, TP, and SRP, are slightly increased in bottom waters compared to the surface samples. Oxygen ranged from 9 to $15 \mathrm{mgO}_{2} / \mathrm{L}$ in surface waters but was totally depleted in the bottom waters of some lakes. Silicate was depleted in surface waters and enriched in the hypolimnion. $\mathrm{Mg}, \mathrm{DOC}, \mathrm{NO}_{\overline{3}}^{-}, \mathrm{Na}$, and $\mathrm{K}$, however, were distributed equally in the water column.

Dissolution of calcium carbonate dominates the composition of surface as well as bottom waters of the sampled lakes, depending on $\mathrm{pH}$ that, again, is influenced by the partial pressure of $\mathrm{CO}_{2}\left(\mathrm{p}_{\mathrm{CO}_{2}}\right)$. Figure 2 shows ion products of measured $\mathrm{Ca}^{+2}$ and $\mathrm{CO}_{3}^{-2}$; concentration of $\mathrm{CO}_{3}^{-2}$ was calculated from alkalinity and $\mathrm{pH}$ according to eq. (2):

$$
\left[\mathrm{CO}_{3}^{-2}\right]=\frac{\mathrm{Alk}}{\frac{\left[\mathrm{H}^{+}\right]}{\mathrm{K}_{2}}+2}
$$

(assuming that all alkalinity originates from carbonate species) and the equilibrium constants $\log \mathrm{K}_{2}$ for $5{ }^{\circ} \mathrm{C}$ (hypolimnion) -10.56) and $20^{\circ} \mathrm{C}$ (epilimnion) - 10.38 , respectively (Stumm and Morgan, 1996). It indicates calcite oversaturation in surface waters where photosynthetically decreased $\mathrm{p}_{\mathrm{CO}_{2}}$ has increased the $\mathrm{pH}$. The hypo- 


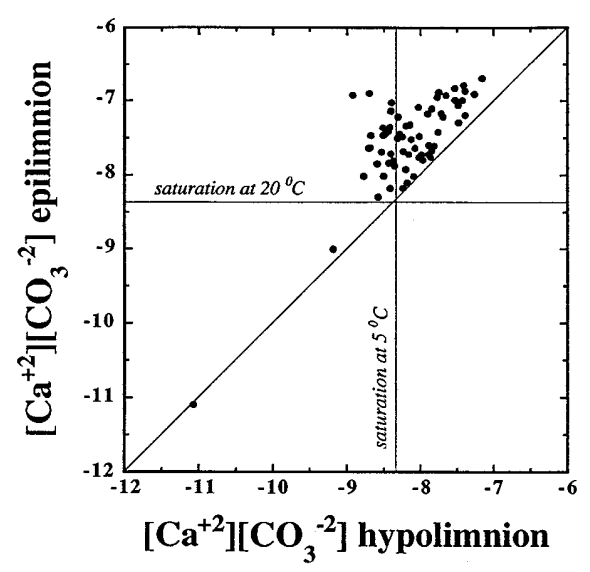

Figure 2. Ion products of $\left[\mathrm{Ca}^{+2}\right]$ and $\left[\mathrm{CO}_{3}^{-2}\right]$ as determined in surface and bottom waters. The lines for calcite saturation were calculated with constants for $20^{\circ} \mathrm{C}$ for surface and $5{ }^{\circ} \mathrm{C}$ in bottom water (constants from Stumm and Morgan, 1996)

limnia, however, are at saturation with respect to calcite. $\mathrm{pH}$ values extend down to 7 due to mineralization processes. The ion product $\left[\mathrm{Ca}^{+2}\right]\left[\mathrm{CO}_{3}^{-2}\right]$ for all lakes is higher in their epilimnia than in the hypolimnia.

The processes of assimilation and mineralization are reflected in the correlations of the chemical parameters in surface and bottom waters: High concentrations of $\mathrm{O}_{2}$ in surface waters (Table 2a) coincide with high TP, TN, and DOC concentrations. In bottom waters (Table $2 \mathrm{~b}$ ) TP and $\mathrm{O}_{2}$ are (weakly) negatively correlated, and high $\mathrm{PO}_{4}$ and TN occur with high TP. Geogenic parameters (Ca, Mg, Na, K, Alk), with the exception of silicate, are correlated with high significance levels. High concentrations of DOC in hypolimnetic waters correlate with high concentrations of TN, alkalinity, $\mathrm{K}, \mathrm{Ca}, \mathrm{Na}, \mathrm{Mg}$, and $\mathrm{CO}_{2}$. In both surface and bottom water layers we find generally positive correlations between nutrient parameters $\left(\mathrm{NO}_{3}^{-}, \mathrm{TN}, \mathrm{SiO}_{2}\right)$ and geogenic parameters $(\mathrm{Ca}, \mathrm{Mg}, \mathrm{Na}, \mathrm{K}$, alkalinity), except the phosphorus components, $\mathrm{pH}$, and $\mathrm{O}_{2}$. TP correlates with $\mathrm{K}$ and DOC. $\mathrm{pH}$ is allusively inversely correlated with the former parameters.

There are no obvious correlations of any chemical parameters with the maximum lake depths.

\section{The influence of the catchment area}

We classified the catchment according to the following five categories: bare land, green but unwooded land, forested land, agricultural land, and urban areas (see Appendix III). Increased levels of $\mathrm{NO}_{3}^{-}, \mathrm{TN}$, and $\mathrm{TP}$ occur preferentially in catchment areas with high percentages of agricultural land use. Land use is reflected in the water transparency since Secchi depth tends to be higher in catchments with little agriculture.

Figure 3 a shows the distribution of $\mathrm{TN}$ in the epilimnetic waters in relation to agriculture in the catchment area. Consequently, the concentrations of nutrients are 
Table 2. Pearson correlation matrix of chemical parameters (a) in surface waters, (b) in bottom waters, and (c) in sediments. Bold numbers signify correlations with significance levels $\mathrm{p}<0.01$

\begin{tabular}{lrrrrrrrrrrrrr}
\hline & $\mathrm{SiO}_{2}$ & $\mathrm{~K}$ & $\mathrm{Na}$ & $\mathrm{Mg}$ & $\mathrm{Ca}$ & $\mathrm{P}_{\text {tot }}$ & $\mathrm{PO}_{4}$ & $\mathrm{~N}_{\text {tot }}$ & $\mathrm{NO}_{3}$ & DOC & Alk & $\mathrm{pH}$ & $\mathrm{O}_{2}$ \\
\hline $\mathrm{SiO}_{2}$ & 1.000 & & & & & & & & & & & & \\
$\mathrm{~K}$ & 0.047 & 1.000 & & & & & & & & & & & \\
$\mathrm{Na}$ & 0.008 & $\mathbf{0 . 7 2 1}$ & 1.000 & & & & & & & & & & \\
$\mathrm{Mg}$ & 0.218 & $\mathbf{0 . 5 7 3}$ & 0.456 & 1.000 & & & & & & & & & \\
$\mathrm{Ca}$ & 0.088 & $\mathbf{0 . 7 2 8}$ & 0.508 & $\mathbf{0 . 5 9 8}$ & 1.000 & & & & & & & & \\
$\mathrm{P}_{\text {tot }}$ & 0.004 & $\mathbf{0 . 7 2 9}$ & 0.473 & 0.302 & 0.474 & 1.000 & & & & & & & \\
$\mathrm{PO}_{4}$ & 0.022 & 0.335 & 0.116 & 0.125 & 0.187 & 0.367 & 1.000 & & & & & & \\
$\mathrm{~N}_{\text {tot }}$ & 0.233 & $\mathbf{0 . 8 0 5}$ & 0.547 & $\mathbf{0 . 6 9 0}$ & $\mathbf{0 . 8 1 8}$ & 0.551 & 0.170 & 1.000 & & & & & \\
$\mathrm{NO}_{3}$ & 0.216 & $\mathbf{0 . 6 3 1}$ & 0.430 & $\mathbf{0 . 5 8 4}$ & $\mathbf{0 . 6 9 3}$ & 0.399 & 0.132 & $\mathbf{0 . 8 9 6}$ & 1.000 & & & & \\
$\mathrm{DOC}-0.025$ & $\mathbf{0 . 7 9 4}$ & $\mathbf{0 . 5 7 5}$ & 0.527 & $\mathbf{0 . 7 6 9}$ & $\mathbf{0 . 6 0 5}$ & 0.289 & $\mathbf{0 . 7 5 6}$ & $\mathbf{0 . 5 7 6}$ & 1.000 & & & \\
$\mathrm{Alk}$ & 0.088 & $\mathbf{0 . 7 3 1}$ & 0.547 & $\mathbf{0 . 7 3 9}$ & $\mathbf{0 . 9 5 3}$ & 0.460 & 0.167 & $\mathbf{0 . 8 1 2}$ & $\mathbf{0 . 6 6 7}$ & $\mathbf{0 . 7 7 2}$ & 1.000 & & \\
$\mathrm{pH}_{\mathrm{O}}$ & -0.354 & -0.110 & -0.088 & -0.047 & -0.128 & -0.038 & -0.247 & -0.188 & -0.163 & -0.037 & -0.079 & 1.000 & \\
$\mathrm{O}_{2}$ & -0.046 & $\mathbf{0 . 6 3 6}$ & 0.568 & 0.442 & 0.429 & $\mathbf{0 . 6 3 3}$ & 0.015 & 0.529 & 0.429 & 0.481 & 0.422 & 0.194 & 1.000 \\
\hline
\end{tabular}

$\begin{array}{lllllllllllll}\mathrm{SiO}_{2} & \mathrm{~K} & \mathrm{Na} & \mathrm{Mg} & \mathrm{Ca} & \mathrm{P}_{\text {tot }} & \mathrm{PO}_{4} & \mathrm{~N}_{\text {tot }} & \mathrm{NO}_{3} & \mathrm{DOC} & \mathrm{Alk} & \mathrm{pH} & \mathrm{O}_{2}\end{array}$

\begin{tabular}{|c|c|c|c|c|c|c|c|c|c|c|c|c|}
\hline $\mathrm{SiO}_{2}$ & 1.000 & & & & & & & & & & & \\
\hline & 0.094 & 1.000 & & & & & & & & & & \\
\hline $\mathrm{Na}$ & 0.070 & 0.574 & 1.000 & & & & & & & & & \\
\hline $\mathrm{Mg}$ & 0.329 & 0.541 & 0.328 & 1.000 & & & & & & & & \\
\hline $\mathrm{Ca}$ & 0.173 & 0.709 & 0.401 & 0.578 & 1.000 & & & & & & & \\
\hline $\mathrm{P}_{\text {tot }}$ & 0.258 & 0.215 & 0.524 & -0.058 & 0.184 & 1.000 & & & & & & \\
\hline $\mathrm{PO}_{4}$ & 0.136 & 0.158 & 0.730 & -0.085 & 0.084 & 0.885 & 1.000 & & & & & \\
\hline $\mathrm{N}_{\text {tot }}$ & 0.304 & 0.675 & 0.492 & 0.575 & 0.713 & 0.517 & 0.361 & 1.000 & & & & \\
\hline $\mathrm{NO}_{3}$ & 0.072 & 0.627 & 0.326 & 0.655 & 0.697 & -0.081 & -0.106 & $\mathbf{0 . 7 2 4}$ & 1.000 & & & \\
\hline DOC & 0.155 & 0.729 & 0.425 & 0.485 & 0.690 & 0.189 & 0.117 & 0.649 & 0.524 & 1.000 & & \\
\hline Alk & 0.273 & 0.707 & 0.433 & 0.720 & 0.902 & 0.226 & 0.116 & $\mathbf{0 . 7 7 0}$ & 0.667 & $\mathbf{0 . 7 7 2} 1.000$ & & \\
\hline $\mathrm{pH}$ & -0.395 & -0.304 & -0.340 & -0.164 & -0.247 & -0.442 & -0.362 & -0.314 & 0.017 & $-0.432-0.330$ & 1.000 & \\
\hline $\mathrm{O}_{2}$ & -0.395 & -0.025 & -0.096 & 0.012 & -0.043 & -0.380 & -0.325 & -0.096 & 0.236 & $-0.176-0.167$ & $7 \mathbf{0 . 6 3 2}$ & 1.000 \\
\hline
\end{tabular}

\begin{tabular}{lrrrrrrrrr}
\hline & \multicolumn{1}{c}{$\mathrm{N}_{\text {tot }}$} & $\mathrm{C}_{\text {tot }}$ & $\mathrm{C}_{\text {inorg }}$ & $\mathrm{C}_{\text {org }}$ & $\mathrm{CaCO}_{3}$ & $\mathrm{Ca}$ & $\mathrm{Mg}$ & $\mathrm{Na}$ & $\mathrm{K}$ \\
\hline $\mathrm{N}_{\text {tot }}$ & 1.000 & & & & & & & & \\
$\mathrm{C}_{\text {tot }}$ & $\mathbf{0 . 7 6 7}$ & 1.000 & & & & & & & \\
$\mathrm{C}_{\text {inorg }}$ & -0.251 & 0.398 & 1.000 & & & & & & \\
$\mathrm{C}_{\text {org }}$ & $\mathbf{0 . 9 7 7}$ & $\mathbf{0 . 7 9 6}$ & -0.239 & 1.000 & & & & & \\
$\mathrm{CaCO}_{3}$ & -0.251 & 0.396 & $\mathbf{1 . 0 0 0}$ & -0.239 & 1.000 & & & & \\
$\mathrm{Ca}$ & -0.207 & 0.435 & $\mathbf{0 . 9 8 9}$ & -0.192 & $\mathbf{0 . 9 8 9}$ & 1.000 & & & \\
$\mathrm{Mg}$ & -0.140 & -0.254 & -0.121 & -0.189 & -0.121 & -0.231 & 1.000 & & \\
$\mathrm{Na}$ & -0.358 & $\mathbf{- 0 . 5 9 8}$ & -0.359 & -0.386 & -0.359 & -0.389 & 0.103 & 1.000 & \\
$\mathrm{~K}$ & -0.199 & $\mathbf{- 0 . 6 4 2}$ & -0.700 & -0.218 & -0.700 & $\mathbf{- 0 . 7 1 1}$ & 0.187 & 0.433 & 1.000 \\
\hline
\end{tabular}



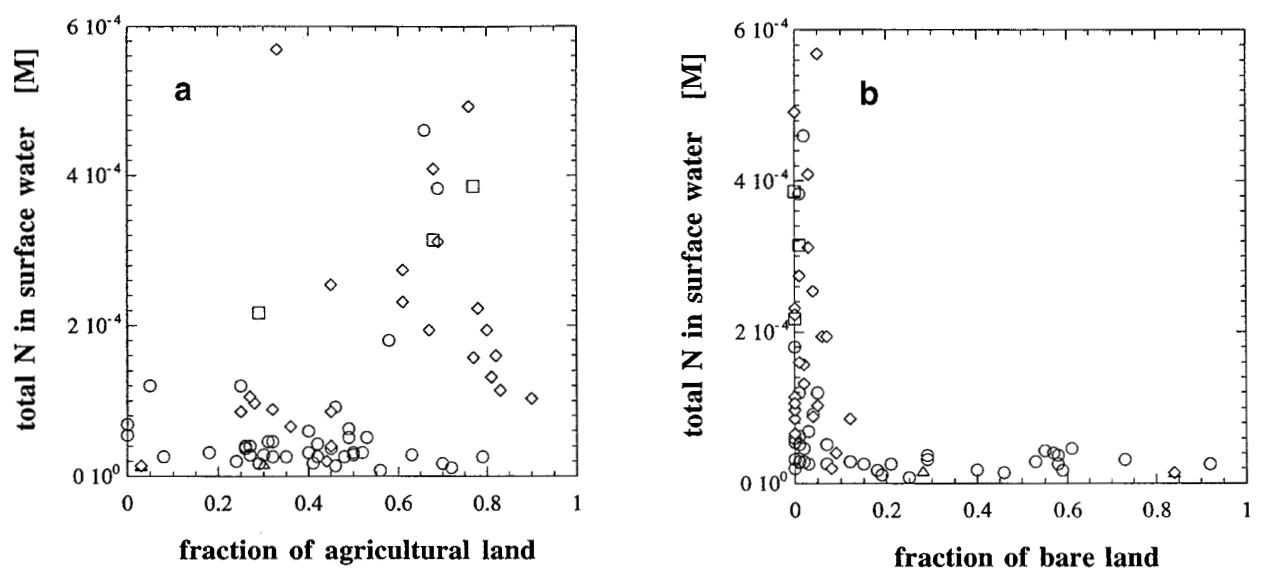

Figure 3. Concentrations of $T N$ in surface waters in relation to the percentage of agriculturally used land (a) and bare land (b) in the catchment area

very low in all catchments with high percentages of bare land (Fig. 3b). Generally, alkalinity, $\mathrm{DOC}, \mathrm{Ca}$, and $\mathrm{Mg}$, are also negatively correlated with the percentage of bare land. The concentrations of $\mathrm{Na}$ and $\mathrm{K}$ increase with the percentage of urban areas. Very low concentrations of TN and total and organic carbon in the sediment occur regularly in areas with a high fraction of bare land in the catchment.

Some remarkable exceptions occur in Figure 3 a where TN in lakes is very low in spite of the high percentage of agriculture in the watershed. Four mesotrophic lakes (OBE, TAN, MEL, and GRO, circles) are all located above $1600 \mathrm{~m}$ a.s.l., and "agriculture" is mostly extensive agriculture and pasture. The relatively low TN of eutrophic lakes (diamonds) in such areas are explained by their individual situation: WIL and MAU have artificial hypolimnetic syphons, BRT has a natural hypolimnetic discharge, HÜN is artificially aerated, and SOP is meromictic.

\section{Altitude}

Parameters indicative for human impact in the catchment areas, such as nitrogen and phosphorus, as well as geogenic parameters, show a remarkable pattern with respect to the elevation of the lakes. It is important to note that there is only a very weak correlation between agricultural land use and altitude $(\mathrm{r}=0.35)$. TN in surface and in bottom waters of lakes situated below $700 \mathrm{~m}$ a.s.l. are all higher than $0.05 \mathrm{mM}$ (surface) and $0.08 \mathrm{mM}$ (bottom) and reach as high as $0.6 \mathrm{mM}$. Above $700 \mathrm{~m}$ a.s.l., however, TN concentrations in surface and in bottom waters are all below $0.05 \mathrm{mM}$ and $0.08 \mathrm{mM}$, respectively (Fig. $4 \mathrm{a}$ ). The same pattern occurs with $\mathrm{NO}_{\overline{3}}$ (Fig. 4b) and TP (Fig. 4c) in epilimnetic water: $\mathrm{NO}_{3}^{-}$concentrations reach up to $0.5 \mathrm{mM}$ in lakes below $700 \mathrm{~m}$ a.s.l. but are below $0.03 \mathrm{mM}$ in all lakes at higher altitudes; TP reaches concentrations up to $2.7 \mu \mathrm{M}$ in lakes below $700 \mathrm{~m}$ a.s.l., but only up to $1 \mu \mathrm{M}$ below $700 \mathrm{~m}$ a.s.l. Lakes with high concentrations of SRP in their surface or bottom waters occur more numerous in low areas. For most lakes, how- 

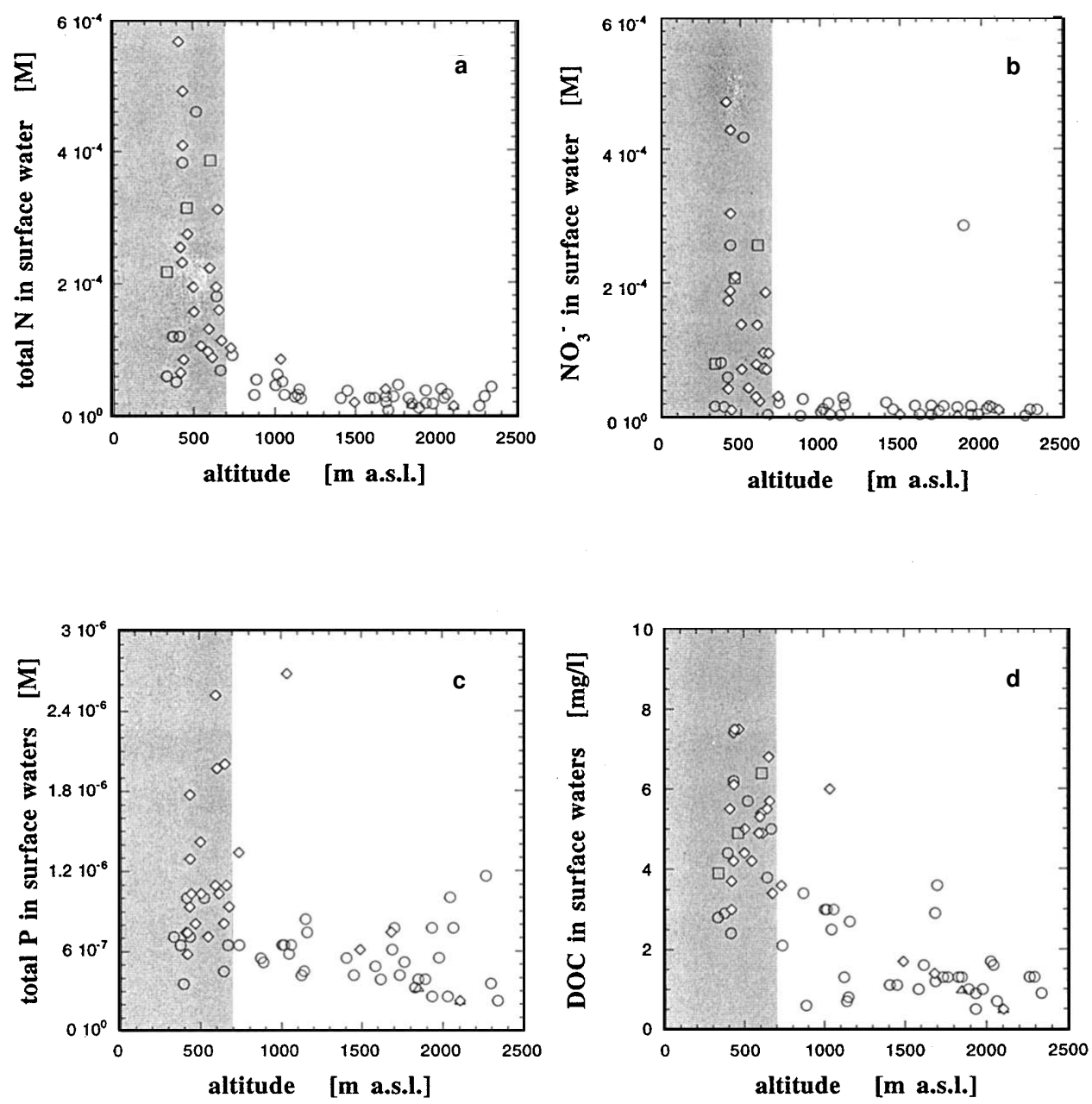

Figure 4. Distribution of $\mathrm{TN}, \mathrm{NO}_{3}^{-}$, $\mathrm{TP}, \mathrm{DOC}, \mathrm{Ca}, \mathrm{Mg}, \mathrm{Na}$, and $\mathrm{K}$, in relation to elevation

ever, concentrations for SRP are at the analytical detection limit. Concentrations of DOC in lakes below $700 \mathrm{~m}$ a.s.l. exceed those of lakes higher than $700 \mathrm{~m}$ a.s.l. (Fig. 4 d) about twofold. The wider range of concentrations at lower altitudes may reflect the wider range of land-use practices: we find more urban areas and more wooded land than at higher altitudes, and almost no bare land. Agriculture, however, is almost evenly distributed at all altitudes.

Moreover, the concentration range of seemingly purely geogenic parameters differs remarkably in lakes above and below $700 \mathrm{~m}$ a.s.l. While in all lakes above $700 \mathrm{~m}$ a.s.l. Ca ranges between $0.5 \mathrm{mM}$ and $1.5 \mathrm{mM}$, more than $50 \%$ of the lakes below $700 \mathrm{~m}$ a.s.l. (surface as well as bottom waters) show concentrations between $1.5 \mathrm{mM}$ and $3 \mathrm{mM}$ (Fig. 4e). The situation for alkalinity is almost identical since 

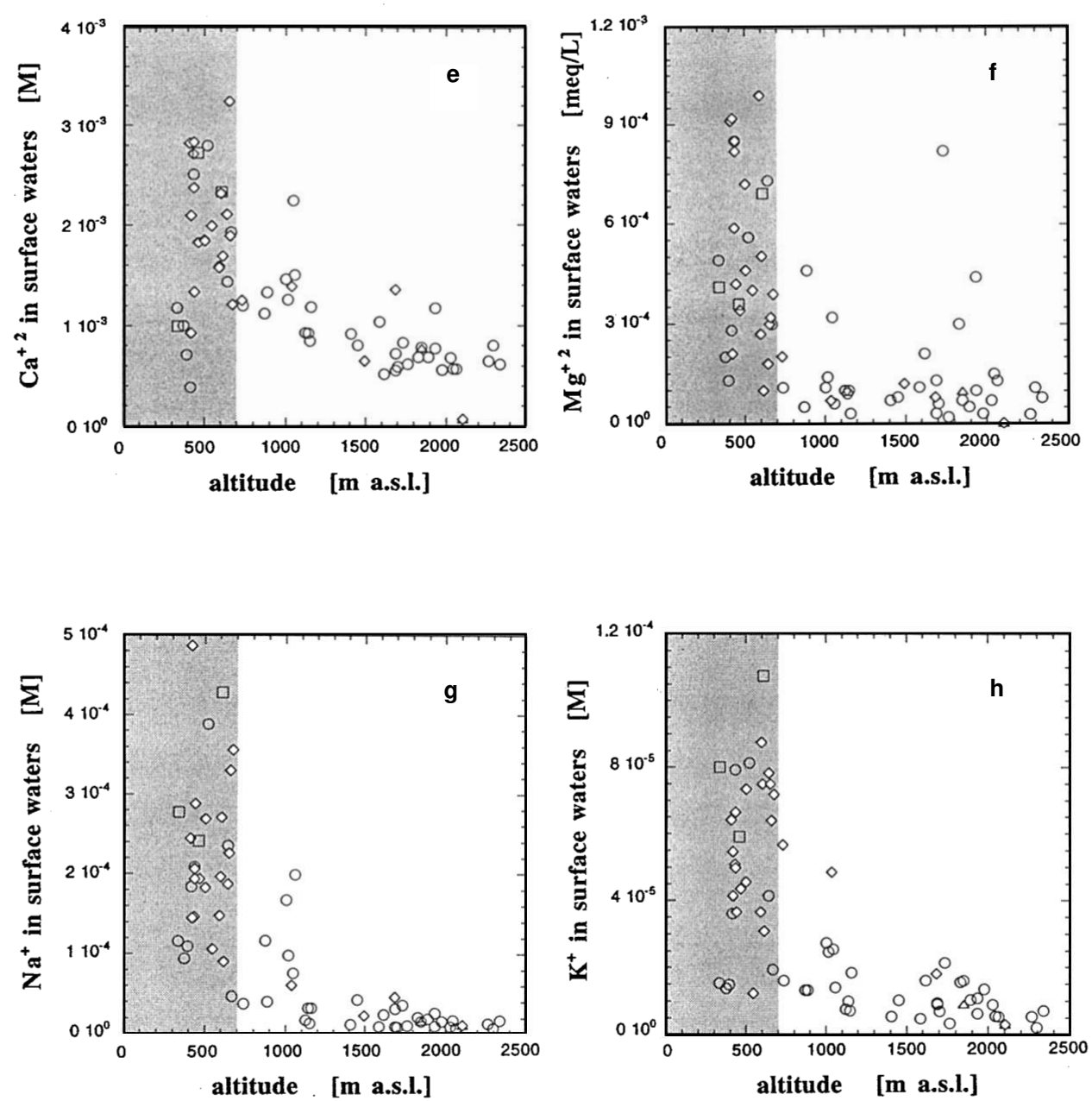

Figure 4 (continued)

$\mathrm{Ca}^{+2}$ and alkalinity are strongly correlated. Alkalinities are 1-3 $\mathrm{mM}$ above and 1-5.5 $\mathrm{mM}$ below $700 \mathrm{~m}$ a.s.l. This effect is even more pronounced for $\mathrm{Mg}$, where average concentrations - with few exceptions - are below $0.2 \mathrm{mM}$ for altitudes higher than $700 \mathrm{~m}$ a.s.l., but above $0.2 \mathrm{mM}$ and up to $1 \mathrm{mM}$ for more than $80 \%$ of the lakes at lower altitudes (Fig. 4f). pH in surface as well as bottom waters tends to be lower below $700 \mathrm{~m}$ a.s.l. Distribution of silicate with altitude is not very pronounced with a few outliers with high concentrations at lower altitudes. $\mathrm{Na}$ and $\mathrm{K}$, however, also reflect this pattern very strongly (Fig. $4 \mathrm{~g}, \mathrm{~h}$ ): in almost all lakes above $700 \mathrm{~m}$ a.s.l. Na concentrations are below $0.1 \mathrm{mM}$ (K below $0.03 \mathrm{mM}$ ) but below $700 \mathrm{~m}$ a.s.l. values up to $0.5 \mathrm{mM}$ (K up to $0.1 \mathrm{mM}$ ) are reached. 


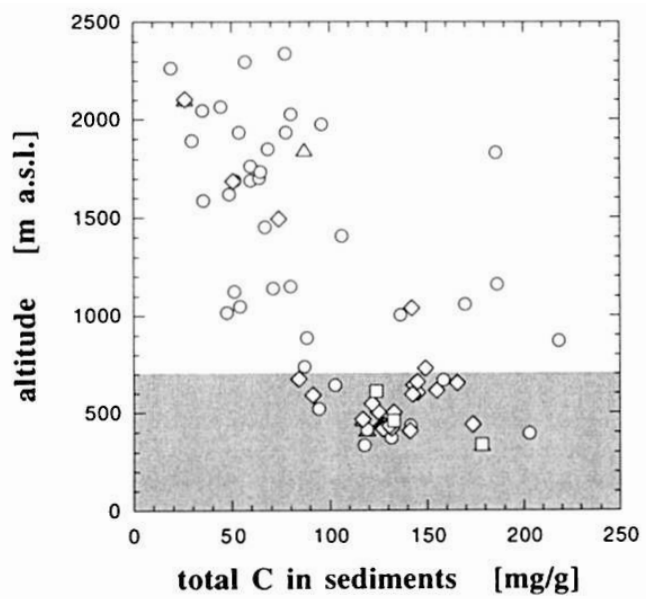

Figure 5. Concentrations of total carbon in the sediments in relation to elevation

\section{Sediments}

The effect of altitude is also reflected in the composition of the sediments. The contents of inorganic and organic carbon are up to two times higher in lake sediments below $700 \mathrm{~m}$ a.s.l. than in those above (Fig. 5). The contents of Fe, $\mathrm{Na}$, and $\mathrm{K}$ in the sediments are higher above $700 \mathrm{~m}$ a.s.l., $\mathrm{Ca}$ and $\mathrm{Sr}$, however, decrease. Concentrations of $\mathrm{Mg}$ and $\mathrm{Mn}$ in lake sediments are not sensitive to altitude.

The maximum lake depth seems to only slightly affect nutrients in the sediments. All lakes with TN in the sediments exceeding $10 \mathrm{~g} / \mathrm{kg}$ and $70 \mathrm{~g} / \mathrm{kg}$ of total organic carbon are shallower than $20 \mathrm{~m}$. Apart from that there was no correlation of chemical sediment parameters with lake depth.

Among the sediment parameters $\mathrm{TN}$ is highly correlated with organic carbon (Table 2c) at a weight ratio of $\mathrm{C}_{\mathrm{org}}: \mathrm{TN}=10: 1$. Practically all inorganic carbon and all $\mathrm{Ca}$ originates from calcite. Ca concentrations are high in sediments of lakes with high $\mathrm{Ca}$ concentrations in their bottom waters. $\mathrm{Na}$ in sediments, however, is high in lakes with low Na concentrations in bottom waters. The same is true for $\mathrm{K}$, though less pronounced.

The concentrations of $\mathrm{N}$ and DOC show strong seasonal fluctuations in the water column. Therefore, our set of samples is not suited to reveal the relationship between sediment and overlaying waters with regard to these parameters. Except for an overall increase in TN and organic carbon in the sediments of lakes with a high hypolimnetic concentration of DOC, none of these sediment parameters (TN, $\mathrm{C}_{\text {inorg }}, \mathrm{C}_{\text {org }}$ ) show any correlations with dissolved ions in the bottom waters. Furthermore, neither of these parameters show any correlation with water depth, $\mathrm{O}_{2}$ contents, alkalinity, or $\mathrm{pH}$ of the hypolimnion. 


\section{Discussion}

\section{Agricultural land-use and altitude}

The chemical composition of a lake reflects the geology, vegetation, and human activities in its catchment area. Our data of epi-, meta-, and hypolimnetic waters from 68 small lakes show high concentrations of $\mathrm{Ca}, \mathrm{Mg}$, and alkalinity typical for hard water lakes in carbonaceous bedrock catchments. The lakes thus are not sensitive to atmospheric acid deposition. The only exception (WAN) is explained by its geological setting in an area of mixed carbonaceous and siliceous bedrock.

Concentration of nutrients ( $\mathrm{N}$ and $\mathrm{P}$ ) in lake waters and sediments are significantly increased in areas with high agricultural land use as illustrated for TN in Figures $6 \mathrm{a}$ and $6 \mathrm{~b}$. This connection is evident even in our temporally widespread water samples and it shows that agricultural activity has by far the most dominant influence on these lake ecosystems. Large fractions of nutrients from agricultural land are known to be transported into rivers and lakes mainly by surface runoff and transport through macropores (e.g., Gächter et al., 1996). Moreover, phosphorus also may be transported by wind erosion from fertilized ground as dust particles. Its contribution to eutrophication as wet and dry deposition, however, is considerably smaller compared to the above mentioned processes (Berner and Berner, 1996). The concentrations of $\mathrm{Na}$ and $\mathrm{K}$ in the investigated lakes are positively correlated with the area of urbanization in the catchment.

The concentrations of all chemical parameters in waters and sediments are lowest in catchments with high amounts of bare land (Fig. 3b). This indicates low erosion and weathering and, therefore, low nutrient concentrations and sediments with very low contents of $\mathrm{N}, \mathrm{P}$, and organic carbon. The main reason for this observations is the increasing fraction of agricultural land at lower altitudes. Bare land and land unsuitable for farming increases with altitude (above $1100 \mathrm{~m}$ a.s.l.). Therefore, we observe increasing nutrient concentrations with increasing agriculture, and decreasing nutrients with increasing altitude as exemplified in Figure 6 for TN in the epilimnetic waters. The most prominent contribution to nutrient concentrations in lakes are agricultural activities in the catchment areas followed by urbanization, whereas green or forested land are minor sources.

However, the geogenic parameters increase at lower altitude due to increased weathering rates and erosion. Higher concentrations of $\mathrm{Ca}, \mathrm{Mg}$, and alkalinity at lower altitudes indicate increased dissolution of calcareous rocks. As mentioned above, we find decreasing concentrations of $\mathrm{Ca}, \mathrm{Mg}$, alkalinity, and DOC with increasing fraction of bare land in the catchment. However, even at altitudes above $1100 \mathrm{~m}$, only a few lakes have catchments areas with $>7-8 \%$ bare land. This indicates that chemical weathering rates are lower at high elevations and larger at low elevations. This phenomenon is supported by the work of Zobrist and Drever (1990) and Drever and Zobrist (1992) who showed exponentially increasing weathering rates of silicate rocks with decreasing elevation in river systems. Low temperatures, thin or absent soils, and short contact times result in less chemical weathering at higher altitudes. Mineral dissolution rates are lower 

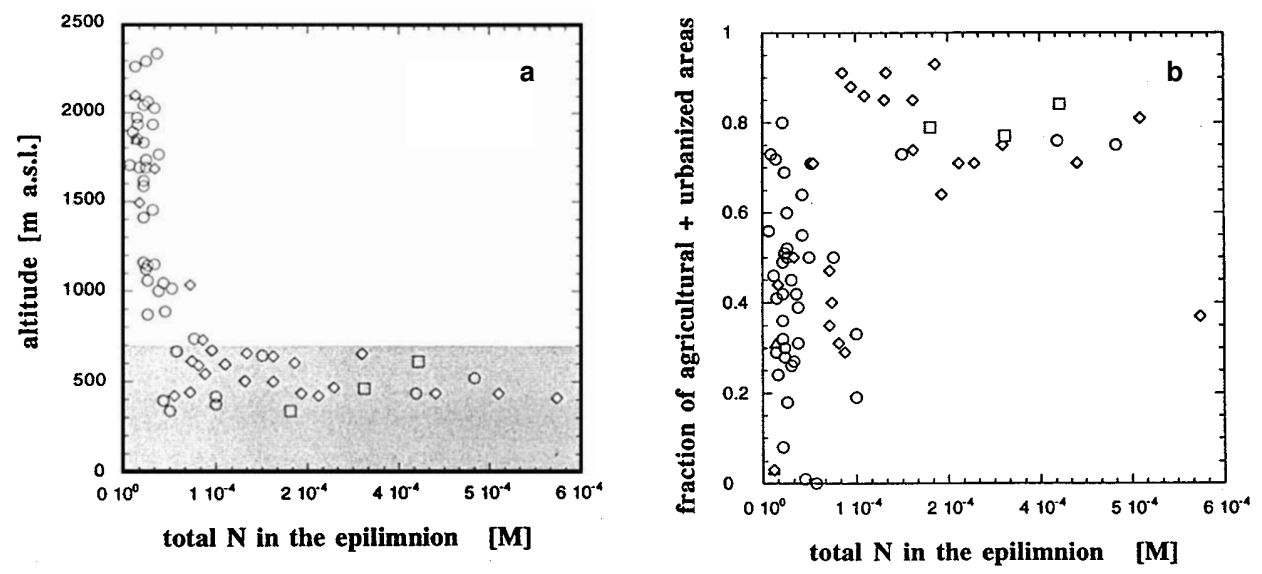

Figure 6. Distribution of epilimnetic TN concentrations in relation to altitude (a) and in relation to land-use (b) in the catchment

at high altitudes not only because of the lower average temperatures (Velbel et al. 1990) but also because of the relative surface area of rocks that is available for weathering reactions. Soil formation produces both large surface areas of minerals and a long residence time of the water compared with naked rock or thin soils. Additionally, the oxidation of reduced nutrients brought out in intensively farmed areas below $700 \mathrm{~m}$ a.s.l. (manure, fertilizer) introduces acidity into the soil. These causes result in the increase of weathering rates that results in higher concentrations of the geogenic parameters. $\mathrm{pH}$ values were found to decrease with decreasing altitude of the lakes. Therefore, bottom waters of lakes below $700 \mathrm{~m}$ a.s.l. tend to be higher in alkalinity, $\mathrm{Ca}$, and $\mathrm{Mg}$. Further contributions to this effect are infiltration of $\mathrm{CO}_{2}$ rich groundwater with high concentrations of dissolved minerals as well as input and transport of reduced matter to the sediment whose mineralization causes the formation of $\mathrm{CO}_{2}$, a drop in $\mathrm{pH}$, dissolution of calcite, and an increase in alkalinity. This finding also indicates that groundwater infiltration to small lakes at high altitudes forms not a major contribution to the water composition.

However, correlations of the main elements are stronger with altitude than with the amount of agricultural land use. Therefore, other processes can be expected to contribute to this dependency. The sharp separation of lakes with high and low nutrient concentrations along the altitudinal gradient coincides with the altitude of meteorological situations where cold air is trapped under layers of warmer air. This climatic inversion situation is quite common in perialpine and alpine regions in Switzerland during the winter months (Barry, 1992). Due to the stabilization of the air layers, polluted air can be trapped, spread, and deposited within relatively confined areas below $700-800 \mathrm{~m}$ a.s.l. Because pollutant concentrations of aerosols and dry deposition can be extremely high (POLLUMET, 1990) they may contribute significantly to the direct and indirect nutrient input into the investigated lakes. 


\section{Nutrients}

Most of the investigated lakes have low concentrations of SRP $(<1 \mu \mathrm{mol} / \mathrm{L})$ soon after stratification, but increased PP concentrations were observed in the bottom waters. No significant decrease of $\mathrm{NO}_{3}^{-}$and only sporadic increases in bottom water TN occurred, however. Concentrations of $\mathrm{NO}_{3}^{-}$and $\mathrm{TN}$ exceed $\mathrm{P}$ concentrations by a factor 100-1000. Apart from two lakes (WIL, BUG) which were extremely high in SRP at the deepest sampling point and where no annual mixing took place, only one lake (SOP) had an average SRP concentration as high as $2 \mu \mathrm{mol} / \mathrm{L}$. A second sampling of some lakes in the following winter (mixing situation), however, revealed very high concentrations of SRP $(>2 \mu \mathrm{mol} / \mathrm{L})$ in the epilimnion of several lakes (LOC, SEE, SOP, ROT, INK) although SRP was below $0.5 \mu \mathrm{mol} / \mathrm{L}$ in the springtime of the previous year. Only SRP, and not $\mathrm{NO}_{3}^{-}$, was increased in these lakes.

Two lakes sampled at the end of March (WIL, BUG) were devoid of hypolimnetic oxygen and showed very high concentrations of dissolved and particulate phosphorus. Both lakes are meromictic. Concentrations of SRP were exceedingly high $(25 \mu \mathrm{mol} / \mathrm{L}$ and $12 \mu \mathrm{mol} / \mathrm{L})$ and so were concentrations of TP $(29 \mu \mathrm{mol} / \mathrm{L}$ and $36 \mu \mathrm{mol} / \mathrm{L})$. In all lakes there was no significant increase in SRP as long as there were traces of $\mathrm{O}_{2}$ detectable. However, PP increased by approximately a factor of two in all cases where $\mathrm{O}_{2}$ was below $1 \mathrm{mg} / \mathrm{L}$, but still detectable (ROT, CHV, GRO, SEB, BRT, OBE, TÜR, EGE, DIT). This could be due to adsorption of phosphate onto iron oxide particles (Hupfer et al., 1995). Therefore, PN does not follow the increase of particulate phosphorus in these cases. Nitrate was at the detection limit in the bottom waters of both lakes due to denitrification. TN was increased, however, and so were alkalinity, $\mathrm{Ca}$, and $\mathrm{SiO}_{2}$ (but not DOC), resulting in a very high ion concentration as reflected also by the conductivity data. Obviously, these lakes did not undergo mixing during the cold season due to high salt density gradients in their bottom waters (Wüest et al, 1992; Imboden and Wüest, 1995). An indication for density induced stabilization is also the higher water temperature of the bottom waters compared to the overlaying waters.

With its extremely low ion concentrations, low concentrations of $\mathrm{PN}, \mathrm{P}$, and DOC, and low $\mathrm{pH}$, one lake (WAN) immediately attracts attention. The fact that this is the only lake whose catchment is situated at a geological transition zone between carbonaceous and siliceous bedrock explains the special situation. Nevertheless, the general trends in concentration differences between surface and bottom waters agree with the processes discussed for the other lakes.

\section{The origin of nitrogen: a conceptual approach}

To discuss the origin of nitrogen in the 68 investigated lakes in more detail we use a simple, conceptual approach. Mass balances of nitrogen in lakes are described in a one box model by the input (from soils and atmosphere), outflow, and the amount of nitrogen eliminated by sedimentation and denitrification:

$$
\mathrm{V} \frac{\mathrm{dN}}{\mathrm{dt}}=\mathrm{Q}\left[\mathrm{N}_{\text {in }}\right]-\mathrm{Q}\left[\mathrm{N}_{\text {out }}\right]-\sigma \mathrm{V}[\mathrm{N}]
$$


Lake volumes $(\mathrm{V})$ were taken either from literature if available or estimated using lake surface area, maximum depth, and a multiplication factor of 0.56 estimated from literature data on areas, volumes, and depths of lakes. Throughflows of water (Q) were estimated from detailed data in the Swiss Hydrological Atlas (1992) on annual precipitation and the amount of water flowing out of certain catchment areas averaged over 20 years (1961-1980). $\sigma$ indicates the fraction of nitrogen in the lake eliminated by sedimentation and denitrification. Mean water residence times $\tau_{\mathrm{w}}(=\mathrm{V} / \mathrm{Q})$ or the flow rate $\rho\left(=1 / \tau_{\mathrm{w}}\right)$ were calculated from these data. In steady state conditions $(\mathrm{dN} / \mathrm{dt}=0)$ eq. 3 turns to:

$$
\mathrm{N}=\mathrm{N}_{\mathrm{in}} \cdot \frac{\rho}{\rho+\sigma}
$$

Our data show increasing values for the flow rates and decreasing TN concentrations for lakes with increasing altitudes. Nitrogen concentrations in high altitude lakes are rather low. This may be due to several reasons. First, there is increasing precipitation at high altitudes resulting in higher mean flow rates per catchment area compared to lowland lakes. Second, flows at high altitudes depend on the season, showing extremely high rates at snowmelt in spring and summer and very low rates during winter when the catchment is snow-covered or frozen. At a very slow flow rate (i.e., a long residence time) the effect of elimination reactions on the concentration of TN may be considerable, whereas it becomes less important with increasing flow rate. Third, the factor for elimination of nitrogen from lake water $(\sigma)$ decreases with increasing altitude due to reduced photosynthetic activity, and denitrification rates may be smaller due to lower temperatures. Similarly, less phosphate results in smaller production, less uptake of nitrate, less sedimentation of nitrogen and, therefore, smaller $\sigma$.

Hence, we can explain steady state nitrogen concentrations at higher altitudes to be close to input concentrations, whereas elimination reactions are more effective at lower altitudes.

Estimates can be made whether the nitrogen concentrations may be explained by mere atmospheric input through rain or whether additional sources must be considered. The input of nitrogen by rain was calculated from the annual rainfall and the TN concentrations in rainwater of two locations (Zobrist, 1983). Jungfraujoch in the Swiss Alps (3570 m a.s.l.) is an example for unpolluted rain $\left(10^{-5} \mathrm{~mol} / \mathrm{L}\right)$, whereas Dübendorf, close to the city of Zürich, is characteristic for a polluted urban area $\left(3.4 \cdot 10^{-5} \mathrm{~mol} / \mathrm{L}\right)$. Values for $\mathrm{Q}$ were calculated as described above.

Despite the rough estimates the conclusions from the data are unambiguous. The concentrations of TN of 24 lakes are smaller (less than 50\%) than estimated from the unpolluted rain. These lakes - with one exception - are all located above $1000 \mathrm{~m}$ a.s.l. The average part of agriculture in the catchment area is $38 \%$. These lakes are characterized by very short residence times (average $\tau_{\mathrm{w}}=26$ days).

$\mathrm{TN}$ concentrations of 11 lakes are comparable to the concentrations estimated from unpolluted rain $( \pm 100 \%)$. Six of them are situated above $880 \mathrm{~m}$ a.s.l. The agricultural part of the catchment of only 3 of these lakes is larger than $45 \%$, and the residence times are short (average $\tau_{\mathrm{w}}=2.9$ months). Furthermore, ten out of these 
eleven lakes have $\mathrm{K}$ concentrations similar (within a factor of two) to those measured in the Jungfraujoch precipitation, and five have similar Na concentrations.

Our dataset contains 16 lakes whose lakewater TN concentrations agree with the estimate of a polluted rain such as from Dübendorf; 14 of these lakes are below $700 \mathrm{~m}$ a.s.l., and eight lakes have $>70 \%$ agricultural land in the catchment. Mean residence time is 5.5 months.

TN concentrations in 8 lakes are more than a factor of two higher than estimated from the polluted rain. All of them are located below $640 \mathrm{~m}$ a.s.l.; $68 \%$ of the land is in agricultural use, and the mean hydrological residence times is 11 months.

These findings indicate that precipitation is responsible for a certain background concentration of nitrogen and that increasing amounts of nitrogen originate from agricultural activities especially in lakes at low altitudes with long hydrological residence times.

\section{Conclusions}

The chemical analyses of epilimnetic and hypolimnetic water and surficial sediments of 68 circumalpine lakes show that environmental factors of the catchment areas strongly affect the water composition of the lakes. Lakes with a high percentage of agricultural and urban land-use show significantly higher concentrations of nitrogen and phosphorus than lakes with a high fraction of bare, green, or forested land in their catchment. Increased concentrations of TN occur in locations of low altitude and high percentage of agricultural land-use. We explain our set of nutrient data with two causes, namely precipitation and intense farming activities in the catchment. Low levels of TN in remote lakes can be attributed to unpolluted precipitation, and contribution from farming is not obvious. Two thirds of the lakes located below $700 \mathrm{~m}$ a.s.l. show TN concentrations corresponding to the composition of a polluted urban precipitation. Nitrogen contents of the remaining eight lakes are distinctly higher, indicating that agriculture which covers two thirds of the land in their catchment is the likely cause.

Nutrient concentrations in the lakes increase with residence times which also increase in lakes at lower altitude. Concentrations are generally two to three times lower and vary in a narrower range at altitudes above $700 \mathrm{~m}$ a.s.l., than in lakes located below $700 \mathrm{~m}$ a.s.l. This may reflect the wider range of land-use practices in catchments below $700 \mathrm{~m}$ a.s.l.

A strong correlation of $\mathrm{Ca}, \mathrm{Mg}, \mathrm{Na}, \mathrm{K}$, and alkalinity with altitude indicates increased weathering rates at lower altitude. The concentrations of $\mathrm{Na}$ and $\mathrm{K}$ increase with increasing percentage of urbanized areas in the watershed.

\section{ACKNOWLEDGEMENTS}

The help of many people that contributed to this work is gratefully acknowledged: A. Zwyssig, E. Grieder and C. Stengel for the lake sampling, T. Rüttimann and F. Bürgi for the chemical analysis. L. Garibaldi and the cantonal environmental protection agencies made generously available chemical data of many lakes. We are grateful for valuable suggestions from René Gächter and two anonymous reviewers that helped to improve the manuscript. This project was financially supported by the Swiss Priority Programme Environment grant no 5000-034876. 


\section{REFERENCES}

Anderson N.J. and R.W. Battarbee, 1994. Aquatic community persistence and variability: a palaeolimnological perspective. In: P.S. Giller, A.G. Hildrew, \& D. Raffaelli, (eds.) Aquatic Ecology: Scale, Patterns and Processes. Blackwell Scientific Publications, London. 233-259.

Barry R.G. 1992. Mountain weather and climate, 2nd ed. Routledge, London. 402 pp.

Berner E.K. and R.A. Berner, 1996. Global Environment: water, air, and geochemical cycles, p. 227. Prentice Hall, Inc.

Brenner M. and M.W. Binford, 1988. Relationship between concentration of sedimentary variables and trophic state in Florida lakes. Can. J. Fish. Aquat. Sci. 45:294-300.

Catalan J. and Fee, E.J., 1994, Interannual variability in limnic ecosystems: origin, patterns, and predictability. In: R. Margalef (ed.), Limnology Now: A Paradigm of Planetary Problems. Elsevier Science B.V. 81-97.

DEW 1996, Deutsche Einheitsverfahren zur Wasseruntersuchung, Bd. II, VCH Weinheim, New York, Basel, Cambridge, Tokyo; Beuth Berlin, Wien, Zurich.

Drever J. I. and J. Zobrist, 1992. Chemical weathering of silicate rocks as a function of elevation in the southern Swiss Alps. Geochim. Cosmochim. Acta 56:3209-3216.

Gächter R., A. Mares, Ch. Stamm, U. Kunze and J. Blum, 1996. Dünger düngt Sempachersee. Agrarforschung 3(7):329-332.

Hupfer M., R. Gächter, and R. Giovanoli, 1995. Transformation of phosphorous species settling seston and during early sediment diagenesis. Aquatic Sci. 57:305-324.

Hydrological Atlas of Switzerland, 1992. Landeshydrologie und -geologie, EDMZ, CH-3003 Berne.

Imboden D.M. and A. Wüest, 1995. Mixing Mechanisms in Lakes. In: A. Lerman, D. Imboden, J. Gat (eds.) Physics and Chemistry of Lakes. 2nd ed., Springer Verlag, Heidelberg, p. $83-138$.

Larsen J., J.F. Boyle, and H.J.B. Birks, 1996. Variation in the geochemistry of recent lake sediments along a west-east pollution gradient in the Bergen area, Norway. Water, Air, and Soil Pollution 88:47-81.

Livingstone D.M. and D. Imboden, 1996. The prediction of hypolimnetic oxygen profiles: a plea for a deductive approach. Can. J. Fish. Aquat. Sci. 53:924-932.

Lotter, A.F., H.J.B. Birks, W. Hofmann and A. Marchetto, 1997a. Modern diatom, cladocera, chironomid, and chrysophyte cyst assemblages as quantitative indicators for the reconstruction of past environmental conditions in the Alps. I. Climate. Journal of Paleolimnology, 18: $395-420$.

Lotter, A.F., H.J.B. Birks, W. Hofmann and A. Marchetto, 1997b. Modern diatom, cladocera, chironomid, and chrysophyte cyst assemblages as quantitative indicators for the reconstruction of past environmental conditions in the Alps. II. Nutrients. Journal of Paleolimnology, in press.

Margalef, R., 1994. The place of epicontinental waters in global ecology. In: R. Margalef (ed.) Limnology Now: A Paradigm of Planetary Problems. Elsevier Science B.V. 1-8.

Müller B., 1995. ChemEQL V2.0, A program to calculate chemical speciation equilibria. Internal report, EAWAG, CH-6047 Kastanienbaum, Switzerland.

OECD, 1982. Eutrophisation des eaux. Méthodes de surveillance, d'évaluation et de lutte. OCDE, Paris. 174 pp.

Pienitz, R. and J.P. Smol, 1993. Diatom assemblages and their relationship to environmental variables in lakes from the boreal forest-tundra ecotone near Yellowknife, Northwest Territories, Canada. Hydrobiologia 269/270:391-404.

POLLUMET, 1990. Luftverschmutzung und Meteorologie in der Schweiz, B. Neininger and J. Dommen, 2nd ed. Zuerich.

Psenner, R. and Schmidt, R., 1992. Climate-driven pH control of remote alpine lakes and effects of acid deposition. Nature 356:781-783.

Schindler, D.W., 1987. Detecting ecosystem response to anthropogenic stress. Can. J. Fish. Aquat. Sci. 44:6-25.

Stumm W. and J.J. Morgan, 1996. Aquatic Chemistry, 3rd ed., Wiley.

Velbel M.A., A.B. Taylor and N.L. Romero, 1990. Effect of temperature on feldspar weathering rates in alpine and non alpine watersheds. Geol. Soc. Amer., Abstr. Prog. 22:49.

Wilkinson L., 1988. SYSTAT: the system for statistics. SYSTAT Inc., Evanston, III. 
Wüest A., W. Aeschbach-Haertig and H. Baur, 1992. Density structure and tritium-helium age of deep hypolimnetic water in the northern basin of lake Lugano. Aquat. Sci. 54:205-218.

Zobrist J., 1983. Die Belastung der schweizerischen Gewässer durch Niederschläge. VDI-Berichte. 500:159-164.

Zobrist J. and J.I. Drever, 1990b. Weathering processes in alpine watersheds sensitive to acidification. In: Pollution research report 20 "Acidification processes in remote mountain lakes", ed. by M. Johannessen, R. Mosello, and H. Barth, CEC Brussels, 149-161.

Received 12 December 1996;

revised manuscript accepted 27 January 1998. 
Appendix I: Chemical analysis of surface water $(20 \mathrm{~cm})$

\begin{tabular}{llllllllllllllll}
\hline no & Abb. & $\mathrm{O}_{2}$ & $\mathrm{pH}$ & $\mathrm{Alk}$ & $\mathrm{DOC}$ & $\mathrm{NO}_{3}$ & $\mathrm{TN}$ & $\mathrm{SRP}$ & $\mathrm{TP}$ & $\mathrm{Ca}$ & $\mathrm{Mg}$ & $\mathrm{Na}$ & $\mathrm{K}$ & $\mathrm{SiO}_{2}$
\end{tabular}

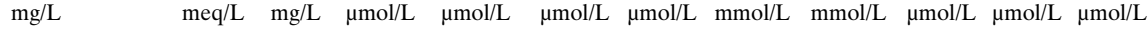

\begin{tabular}{|c|c|c|c|c|c|c|c|c|c|c|c|c|c|c|}
\hline 1 & MUZ & 13.40 & 8.25 & 2.37 & 3.9 & 80.0 & 217.1 & 0.1 & 2.4 & 0.99 & 0.41 & 277.4 & 80.1 & 97.2 \\
\hline 2 & ORI & 11.76 & 7.80 & 0.99 & 2.4 & 59.3 & 120.0 & 0.1 & 1.0 & 0.38 & 0.28 & 183.9 & 36.1 & 118.9 \\
\hline 3 & BUR & 12.76 & 8.00 & 3.02 & 7.5 & 209.3 & 274.3 & 0.1 & 0.8 & 1.82 & 0.34 & 193.5 & 43.5 & 29.5 \\
\hline 4 & MOO & 15.34 & 8.25 & 5.02 & 5.7 & 417.9 & 460.0 & 0.1 & 1.0 & 2.79 & 0.56 & 387.8 & 81.3 & 104.7 \\
\hline 5 & LOC & 16.63 & 8.55 & 5.20 & 4.2 & 188.6 & 231.4 & 0.1 & 0.9 & 2.71 & 0.59 & 146.1 & 50.9 & 6.1 \\
\hline 6 & SEE & 28.88 & 8.50 & 4.50 & 6.4 & 256.4 & 385.7 & 0.2 & 4.2 & 2.33 & 0.69 & 428.3 & 107.4 & 3.9 \\
\hline 7 & GER & 16.32 & 8.55 & 4.48 & 5.4 & 137.9 & 222.9 & 0.1 & 2.0 & 2.31 & 0.50 & 270.9 & 74.9 & 1.8 \\
\hline 8 & UEB & 14.62 & 8.40 & 3.78 & 5.5 & 95.7 & 194.3 & 0.1 & 0.8 & 2.11 & 0.18 & 187.0 & 78.3 & 4.3 \\
\hline 9 & LÜT & 16.31 & 8.50 & 4.28 & 4.4 & 138.6 & 194.3 & 0.2 & 1.4 & 1.85 & 0.72 & 182.6 & 45.5 & 27.1 \\
\hline 10 & WIL & 15.38 & 9.00 & 2.65 & 3.6 & 31.4 & 102.9 & 0.1 & 1.3 & 1.25 & 0.20 & 873.9 & 56.8 & 4.3 \\
\hline 11 & HÜT & 14.35 & 8.40 & 4.59 & 7.4 & 303.6 & 408.6 & 0.5 & 1.3 & 2.37 & 0.82 & 206.5 & 66.5 & 35.6 \\
\hline 12 & HUS & 12.93 & 8.35 & 5.07 & 5.5 & 471.4 & 568.6 & 0.2 & 0.7 & 2.82 & 0.91 & 244.8 & 64.2 & 41.7 \\
\hline 13 & MET & 12.27 & 8.20 & 4.85 & 3.7 & 173.6 & 254.3 & 0.1 & 0.7 & 2.10 & 0.92 & 487.0 & 54.7 & 11.7 \\
\hline 14 & CHA & 15.34 & 8.90 & 2.90 & 7.5 & 10.7 & 85.7 & 0.4 & 1.0 & 1.33 & 0.42 & 287.8 & 36.6 & 1.1 \\
\hline 15 & SOP & 9.19 & 7.80 & 3.16 & 5.3 & 79.3 & 131.4 & 1.3 & 2.5 & 1.59 & 0.27 & 196.5 & 87.5 & 6.4 \\
\hline 16 & BUG & 12.34 & 8.30 & 3.14 & 4.9 & 24.3 & 88.6 & 0.2 & 1.0 & 1.69 & 0.10 & 90.0 & 30.9 & 12.1 \\
\hline 17 & BLA & 11.00 & 8.10 & 2.72 & 0.6 & 27.1 & 54.3 & 0.3 & 0.5 & 1.33 & 0.46 & 40.0 & 13.3 & 58.0 \\
\hline 18 & $\mathrm{SCH}$ & 12.70 & 8.20 & 2.59 & 2.5 & 21.4 & 51.4 & 0.2 & 0.6 & 2.24 & 0.32 & 76.1 & 25.6 & 38.1 \\
\hline 19 & ROT & 13.61 & 8.73 & 1.79 & 3.0 & 42.1 & 65.7 & 0.1 & 0.6 & 0.93 & 0.21 & 144.8 & 41.4 & 3.2 \\
\hline 20 & MAU & 12.29 & 8.33 & 3.75 & 5.0 & 70.7 & 157.1 & 0.1 & 1.0 & 1.84 & 0.46 & 268.7 & 73.4 & 6.4 \\
\hline 21 & SEL & 11.97 & 8.49 & 2.17 & 2.1 & 22.1 & 91.4 & 0.1 & 0.6 & 1.20 & 0.11 & 37.4 & 16.1 & 31.0 \\
\hline 22 & BRE & 10.38 & 8.48 & 2.65 & 3.0 & 7.9 & 45.7 & n.d. & 0.6 & 1.46 & 0.11 & 167.4 & 27.4 & 2.8 \\
\hline 23 & TAI & 11.77 & 8.84 & 2.51 & 6.0 & n.d. & 85.7 & n.d. & 2.7 & 1.38 & 0.07 & 60.9 & 48.6 & 2.8 \\
\hline 24 & SCW & 9.21 & 8.09 & 2.32 & 2.7 & n.d. & 25.7 & n.d. & 0.7 & 1.19 & 0.03 & 32.6 & 18.4 & 7.1 \\
\hline 25 & VOR & 11.77 & 8.89 & 1.79 & 1.3 & 2.9 & 28.6 & n.d. & 0.4 & 0.93 & 0.10 & 17.0 & 7.7 & 3.6 \\
\hline 26 & TSC & 11.86 & 8.20 & 1.58 & 0.8 & 18.6 & 40.0 & 0.1 & 0.8 & 0.84 & 0.10 & 13.5 & 7.2 & 21.7 \\
\hline 27 & $\mathrm{CHV}$ & 9.71 & 8.35 & 1.46 & 1.2 & 17.1 & 28.6 & 0.1 & 0.6 & 0.72 & 0.13 & 9.6 & 9.5 & 19.9 \\
\hline 28 & RET & 11.31 & 8.40 & 2.39 & 1.4 & n.d. & 40.0 & 0.1 & 0.7 & 1.35 & 0.08 & 46.5 & 18.2 & 12.1 \\
\hline 29 & FÄL & 11.40 & 8.80 & 1.70 & 1.1 & 11.4 & 37.1 & 0.1 & 0.4 & 0.80 & 0.08 & 43.0 & 10.2 & 8.9 \\
\hline 30 & SAL & 10.61 & 8.55 & 1.87 & 0.7 & 29.3 & 31.4 & 0.1 & 0.5 & 0.92 & 0.09 & 32.2 & 10.0 & 17.1 \\
\hline 31 & GRO & 10.10 & 8.90 & 1.43 & 1.6 & 4.3 & 25.7 & 0.1 & 0.4 & 0.51 & 0.21 & 24.3 & 16.1 & 5.7 \\
\hline 32 & ENG & 9.00 & 8.40 & 1.48 & 1.3 & 15.0 & 17.1 & 0.1 & 0.4 & 0.78 & 0.07 & 15.7 & 16.1 & 24.9 \\
\hline 33 & SEB & 10.30 & 8.84 & 1.82 & 1.3 & n.d. & 25.7 & 0.1 & 0.3 & 0.68 & 0.30 & 21.3 & 15.6 & 17.1 \\
\hline 34 & TAN & 9.87 & 8.30 & 1.11 & 1.0 & 4.3 & 17.1 & 0.1 & 0.5 & 0.56 & 0.03 & 15.7 & 13.6 & 10.7 \\
\hline 35 & MEL & 9.88 & 8.60 & 1.30 & 1.0 & 285.7 & 11.4 & 0.1 & 0.4 & 0.68 & 0.05 & 19.1 & 10.5 & 15.3 \\
\hline 36 & SEW & 9.54 & 8.61 & 1.06 & 2.9 & 3.6 & 20.0 & 0.1 & 0.6 & 0.55 & 0.03 & 31.7 & 9.0 & 17.4 \\
\hline 37 & BRT & 12.40 & 8.55 & 2.65 & 3.4 & 95.0 & 114.3 & 0.1 & 0.9 & 1.21 & 0.39 & 355.7 & 71.9 & 18.2 \\
\hline 38 & TAY & 10.01 & 8.80 & 1.90 & 1.1 & 22.1 & 25.7 & 0.2 & 0.5 & 0.92 & 0.07 & 12.2 & 5.4 & 15.7 \\
\hline 39 & NER & 11.37 & 8.75 & 1.60 & 1.7 & 3.6 & 20.0 & 0.0 & 0.6 & 0.65 & 0.12 & 23.0 & n.d. & 8.9 \\
\hline 40 & SÄG & 9.18 & 8.27 & 2.29 & 0.9 & 3.6 & 17.9 & 0.1 & 0.8 & 1.17 & 0.10 & 10.0 & 6.4 & 21.0 \\
\hline 41 & WAN & 10.77 & 7.15 & 0.21 & 0.5 & 10.7 & 14.3 & 0.1 & 0.2 & 0.06 & 0.00 & 11.3 & 3.1 & 24.9 \\
\hline 42 & BAN & 9.39 & 8.44 & 2.07 & 1.0 & 17.1 & 25.7 & 0.1 & 0.5 & 1.04 & 0.11 & 9.1 & 4.9 & 20.3 \\
\hline 43 & IFF & 9.85 & 8.50 & 1.31 & 0.7 & 14.3 & 31.4 & 0.1 & 0.8 & 0.57 & 0.13 & 7.4 & 5.4 & 18.9 \\
\hline 44 & FLU & 9.98 & 8.40 & 1.35 & 1.6 & 16.4 & 25.7 & 0.1 & 1.0 & 0.57 & 0.15 & 17.4 & 5.6 & 24.9 \\
\hline 45 & LÄM & 8.80 & 8.55 & 1.82 & 1.3 & 11.4 & 28.6 & 0.1 & 0.4 & 0.80 & 0.11 & 7.0 & 2.0 & 16.7 \\
\hline 46 & TRÜ & 9.26 & 8.39 & 1.08 & 1.3 & 16.4 & 45.7 & 0.1 & 0.5 & 0.61 & 0.02 & 10.4 & 3.3 & 16.0 \\
\hline 47 & $\mathrm{BAC}$ & 10.99 & 8.66 & 1.29 & 1.3 & 2.1 & 14.3 & 0.1 & 1.2 & 0.65 & 0.03 & 13.0 & 5.4 & 18.5 \\
\hline 48 & LUT & 11.25 & 8.84 & 1.27 & 3.6 & n.d. & 7.9 & 0.1 & 0.8 & 0.59 & 0.06 & 8.7 & 6.9 & 9.6 \\
\hline 49 & HAG & 10.12 & 8.32 & 1.25 & 0.9 & 11.4 & 42.9 & 0.1 & 0.2 & 0.61 & 0.08 & 17.4 & 7.2 & 37.0 \\
\hline 50 & GRD & 10.80 & 8.10 & 2.87 & 3.0 & 12.9 & 62.9 & 0.1 & 0.6 & 1.25 & 0.14 & 98.3 & 24.8 & 42.7 \\
\hline 51 & SCE & 11.50 & 8.40 & 1.98 & 0.5 & 16.4 & 37.1 & 0.1 & 0.3 & 0.77 & 0.44 & 26.5 & 11.0 & 57.7 \\
\hline 52 & OBE & 11.80 & 8.65 & 2.60 & 1.3 & 9.3 & 28.6 & 0.1 & 0.4 & 0.83 & 0.82 & 36.1 & 21.5 & 85.8 \\
\hline 53 & TÜR & 9.70 & 8.46 & 3.60 & 3.8 & 72.9 & 180.0 & 0.1 & 0.5 & 1.43 & 0.73 & 235.2 & 41.4 & 10.0 \\
\hline 54 & SWL & 10.00 & 8.60 & 1.58 & 1.7 & 12.1 & 40.0 & 0.1 & 0.3 & 0.68 & 0.07 & 9.1 & 9.0 & 19.9 \\
\hline 55 & $\mathrm{BIC}$ & 12.40 & 8.40 & 4.53 & 4.9 & 30.7 & 97.1 & 0.1 & 1.1 & 1.57 & 0.99 & 147.8 & 36.6 & 10.7 \\
\hline 56 & EGE & 7.10 & 8.05 & 3.95 & 5.0 & 3.6 & 68.6 & 0.1 & 0.6 & 1.93 & 0.30 & 47.0 & 19.4 & 38.4 \\
\hline 57 & DIT & 10.50 & 7.98 & 6.07 & 6.8 & 186.4 & 311.4 & 0.2 & 2.0 & 3.24 & 0.30 & 226.1 & 74.9 & 15.7 \\
\hline 58 & INK & 11.50 & 8.09 & 4.63 & 4.9 & 207.1 & 314.3 & 0.4 & 1.8 & 2.72 & 0.36 & 241.3 & 59.1 & 115.3 \\
\hline 59 & HAS & n.d. & 8.27 & 5.67 & 6.1 & 428.6 & 491.4 & 0.1 & 1.8 & 2.83 & 0.85 & 193.9 & 49.9 & 34.2 \\
\hline 60 & NUS & 11.50 & 8.34 & 5.24 & 6.2 & 256.4 & 382.9 & 0.1 & 0.7 & 2.51 & 0.85 & 209.1 & 79.3 & 24.2 \\
\hline 61 & GAW & 11.20 & 8.39 & 4.36 & 4.2 & 43.6 & 105.7 & 0.2 & 0.7 & 1.99 & 0.40 & 106.1 & 12.3 & 112.5 \\
\hline 62 & HÜN & 13.80 & 8.70 & 4.24 & 5.7 & 71.4 & 160.0 & 0.1 & 1.1 & 1.89 & 0.32 & 330.4 & 63.9 & 3.6 \\
\hline 63 & ROU & 10.20 & 8.55 & 3.11 & 3.0 & 4.3 & 31.4 & 0.1 & 0.6 & 1.50 & 0.06 & 199.1 & 14.1 & 4.6 \\
\hline 64 & ABB & 9.80 & 8.40 & 2.63 & 3.4 & 2.1 & 31.4 & 0.1 & 0.5 & 1.12 & 0.05 & 117.0 & 13.3 & 2.1 \\
\hline 65 & MON & 11.50 & 8.46 & 1.81 & 4.4 & 15.7 & 51.4 & 0.1 & 0.4 & 0.71 & 0.13 & 109.6 & 14.8 & 4.3 \\
\hline 66 & SEG & 12.00 & 8.25 & 2.64 & 2.9 & 81.4 & 120.0 & 0.1 & 0.6 & 1.00 & 0.20 & 93.9 & 13.8 & 19.2 \\
\hline 67 & END & 14.80 & 8.33 & 3.01 & 2.8 & 16.4 & 60.0 & 0.1 & 0.7 & 1.18 & 0.49 & 116.1 & 15.3 & 5.7 \\
\hline 68 & LIO & 8.20 & 8.55 & 1.69 & 1.0 & 5.7 & 16.4 & 0.2 & 0.3 & 0.78 & 0.10 & 16.5 & 9.2 & 15.3 \\
\hline
\end{tabular}


Appendix II: Chemical analysis of bottom waters (1 m above sediment)

\begin{tabular}{llllllllllllllll}
\hline no & Abb. & $\mathrm{O}_{2}$ & $\mathrm{pH}$ & $\mathrm{Alk}$ & $\mathrm{DOC}$ & $\mathrm{NO}_{3}$ & $\mathrm{TN}$ & $\mathrm{SRP}$ & $\mathrm{TP}$ & $\mathrm{Ca}$ & $\mathrm{Mg}$ & $\mathrm{Na}$ & $\mathrm{K}$ & $\mathrm{SiO}_{2}$
\end{tabular}

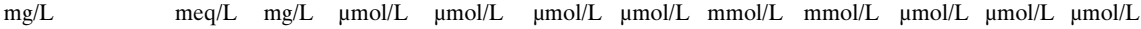

\begin{tabular}{|c|c|c|c|c|c|c|c|c|c|c|c|c|c|c|}
\hline 1 & MUZ & 12.30 & 8.15 & 2.40 & 3.7 & 83.6 & 208.6 & 0.1 & 2.6 & 1.02 & 0.42 & 276.5 & 85.7 & 101.1 \\
\hline 2 & ORI & 12.82 & 7.80 & 0.97 & 2.3 & 60.0 & 125.7 & 0.1 & 0.8 & 0.39 & 0.28 & 183.9 & 34.5 & 114.2 \\
\hline 3 & BUR & 6.00 & 7.60 & 3.62 & 7.9 & 242.1 & 317.1 & 0.7 & 1.8 & 2.12 & 0.38 & 211.7 & 39.4 & 70.8 \\
\hline 4 & MOO & 10.61 & 7.85 & 5.25 & 4.5 & 417.9 & 454.3 & 0.2 & 1.7 & 2.91 & 0.58 & 430.0 & 81.6 & 133.5 \\
\hline 5 & LOC & 14.21 & 8.25 & 5.23 & 4.3 & 182.1 & 222.9 & 0.1 & 1.1 & 2.73 & 0.60 & 148.3 & 47.6 & 15.7 \\
\hline 6 & SEE & 19.68 & 8.05 & 5.03 & 6.4 & 265.7 & 377.1 & 0.2 & 3.7 & 2.62 & 0.69 & 430.9 & 109.0 & 4.3 \\
\hline 7 & GER & 9.93 & 8.00 & 4.57 & 4.7 & 132.1 & 231.4 & 0.1 & 4.3 & 2.34 & 0.51 & 271.3 & 76.0 & 17.4 \\
\hline 8 & UEB & 5.88 & 7.60 & 3.91 & 5.1 & 79.3 & 197.1 & 0.1 & 1.4 & 2.17 & 0.18 & 193.5 & 83.9 & 17.4 \\
\hline 9 & LÜT & 13.68 & 8.15 & 4.72 & 4.6 & 162.1 & 228.6 & 0.2 & 1.0 & 2.03 & 0.76 & 191.7 & 45.0 & 41.6 \\
\hline 10 & WIL & n.d. & 7.10 & 3.60 & 4.5 & 2.9 & 337.1 & 24.8 & 29.0 & 1.60 & 0.22 & 1452.2 & 62.7 & 62.6 \\
\hline 11 & HÜT & 4.64 & 7.70 & 4.91 & 6.3 & 275.0 & 411.4 & 0.3 & 1.1 & 2.49 & 0.85 & 212.6 & 66.8 & 63.3 \\
\hline 12 & HUS & 4.08 & 7.60 & 5.52 & 5.3 & 442.9 & 600.0 & 0.2 & 0.9 & 2.95 & 0.92 & 248.7 & 65.2 & 106.0 \\
\hline 13 & MET & 8.24 & 7.55 & 5.37 & 2.3 & 225.7 & 311.4 & 0.1 & 0.9 & 2.37 & 0.99 & 521.7 & 56.0 & 71.9 \\
\hline 14 & CHA & 13.12 & 7.00 & 3.08 & 6.0 & 6.4 & 117.1 & 0.2 & 0.9 & 1.40 & 0.42 & 294.3 & 36.6 & 53.0 \\
\hline 15 & SOP & 3.34 & 7.50 & 3.20 & 4.2 & 68.6 & 137.1 & 2.4 & 3.8 & 1.58 & 0.28 & 201.7 & 91.3 & 19.2 \\
\hline 16 & BUG & n.d. & 7.00 & 4.86 & 4.0 & 2.1 & 628.6 & 11.9 & 36.0 & 2.28 & 0.11 & 96.5 & 41.7 & 165.1 \\
\hline 17 & BLA & 11.27 & 8.10 & 2.70 & 1.3 & 27.1 & 42.9 & 0.2 & 0.4 & 1.36 & 0.46 & 39.6 & 13.0 & 55.9 \\
\hline 18 & $\mathrm{SCH}$ & 9.63 & 7.90 & 2.82 & 2.0 & 20.0 & 45.7 & 0.2 & 0.6 & 2.85 & 0.40 & 85.7 & 29.2 & 50.2 \\
\hline 19 & ROT & 0.44 & 7.49 & 2.75 & 2.9 & 41.4 & 128.6 & 0.2 & 2.4 & 1.41 & 0.22 & 161.7 & 48.1 & 37.0 \\
\hline 20 & MAU & 9.79 & 7.95 & 4.03 & 4.6 & 41.4 & 128.6 & 0.1 & 1.3 & 2.06 & 0.46 & 265.2 & 73.1 & 18.9 \\
\hline 21 & SEL & 8.91 & 7.88 & 2.21 & 1.8 & 26.4 & 77.1 & 0.1 & 0.7 & 1.22 & 0.11 & 38.3 & 16.1 & 47.0 \\
\hline 22 & BRE & 5.13 & 7.80 & 2.73 & 3.0 & 12.9 & 57.1 & 0.3 & 1.7 & 1.50 & 0.10 & 169.1 & 27.6 & 10.0 \\
\hline 23 & TAI & 1.24 & 7.56 & 2.70 & 5.7 & n.d. & 77.1 & n.d. & 3.1 & 1.48 & 0.07 & 61.3 & 48.6 & 15.3 \\
\hline 24 & SCW & 2.11 & 7.26 & 3.14 & 3.5 & n.d. & 60.0 & n.d. & 1.7 & 1.63 & 0.10 & 41.3 & 36.6 & 56.9 \\
\hline 25 & VOR & 12.27 & 8.85 & 1.85 & 1.3 & 2.9 & 37.1 & n.d. & 0.6 & 0.95 & 0.10 & 14.8 & 7.2 & 5.7 \\
\hline 26 & TSC & n.d. & n.d. & n.d. & n.d. & n.d. & n.d. & n.d. & n.d. & n.d. & n.d. & n.d. & n.d. & n.d. \\
\hline 27 & $\mathrm{CHV}$ & 0.50 & 7.50 & 2.05 & 1.5 & n.d. & 82.9 & 0.3 & 2.7 & 0.95 & 0.15 & 37.4 & 8.2 & 98.9 \\
\hline 28 & RET & 10.42 & 7.90 & 2.76 & 1.5 & n.d. & 51.4 & 0.1 & 1.2 & 1.60 & 0.08 & 41.7 & 25.1 & 41.6 \\
\hline 29 & FÄL & 4.60 & 7.60 & 1.97 & 1.0 & 30.7 & 40.0 & 0.2 & 1.8 & 0.98 & 0.09 & 26.5 & 11.3 & 71.2 \\
\hline 30 & SAL & 12.52 & 8.40 & 1.97 & 0.7 & 33.6 & 182.9 & 0.1 & 0.5 & 0.96 & 0.10 & 24.3 & 22.5 & 24.2 \\
\hline 31 & GRO & 0.38 & 7.45 & 2.60 & 2.0 & n.d. & 62.9 & 0.1 & 1.9 & 0.97 & 0.37 & 44.3 & 39.1 & 68.3 \\
\hline 32 & ENG & 8.40 & 8.15 & 1.74 & 1.1 & 13.6 & 14.3 & 0.1 & 0.4 & 0.93 & 0.09 & 12.6 & 10.0 & 41.6 \\
\hline 33 & SEB & 0.60 & 7.72 & 2.33 & 1.6 & n.d. & 51.4 & 0.1 & 1.7 & 0.92 & 0.35 & 27.0 & 18.7 & 35.9 \\
\hline 34 & TAN & 9.94 & 8.19 & 1.11 & 0.5 & 6.4 & 22.9 & 0.1 & 0.3 & 0.56 & 0.03 & 15.2 & 11.5 & 11.4 \\
\hline 35 & MEL & 9.82 & 8.10 & 1.47 & 0.7 & 6.4 & 14.3 & 0.1 & 0.3 & 0.73 & 0.06 & 19.1 & 9.7 & 22.4 \\
\hline 36 & SEW & 13.97 & 7.97 & 1.55 & 2.3 & 3.6 & 20.0 & 0.1 & 0.8 & 0.79 & 0.04 & 67.4 & 12.5 & 55.9 \\
\hline 37 & BRT & 0.54 & 7.55 & 3.66 & 2.7 & 92.9 & 182.9 & 0.5 & 3.5 & 1.77 & 0.38 & 359.1 & 70.6 & 43.4 \\
\hline 38 & TAY & 4.72 & 7.80 & 2.12 & 1.1 & 27.9 & 37.1 & 0.3 & 0.9 & 1.03 & 0.09 & 13.5 & 17.1 & 41.3 \\
\hline 39 & NER & 7.16 & 7.35 & 2.65 & 3.1 & 3.6 & 68.6 & 0.2 & 2.8 & 1.26 & 0.15 & 32.2 & 20.5 & 67.3 \\
\hline 40 & SÄG & 7.48 & 7.70 & 2.99 & 0.4 & 6.4 & 14.3 & 0.1 & 0.3 & 1.40 & 0.14 & 17.0 & 7.7 & 40.2 \\
\hline 41 & WAN & 10.60 & 7.22 & 0.24 & 0.5 & 6.4 & 14.3 & 0.1 & 0.4 & 0.08 & 0.01 & 13.0 & 4.9 & 26.0 \\
\hline 42 & BAN & 10.00 & 8.35 & 2.19 & 0.7 & 21.4 & 22.9 & 0.1 & 0.4 & 1.14 & 0.11 & 8.7 & 4.6 & 23.8 \\
\hline 43 & IFF & 10.37 & 8.45 & 1.58 & 0.5 & 17.9 & 22.9 & 0.4 & 0.5 & 0.66 & 0.17 & 6.5 & 7.2 & 29.5 \\
\hline 44 & FLU & 10.94 & 8.45 & 1.38 & 0.8 & 17.1 & 34.3 & 0.5 & 0.5 & 0.62 & 0.16 & 17.8 & 2.6 & 27.4 \\
\hline 45 & LÄM & 8.66 & 8.55 & 1.79 & 0.9 & 4.3 & 54.3 & 0.1 & 0.4 & 0.83 & 0.10 & 7.8 & 2.3 & 16.0 \\
\hline 46 & TRÜ & 10.39 & 8.50 & 1.09 & 1.2 & 17.1 & 40.0 & 0.1 & 1.1 & 0.62 & 0.02 & 14.3 & 10.5 & 16.4 \\
\hline 47 & $\mathrm{BAC}$ & n.d. & 8.24 & 1.35 & 0.9 & 5.0 & 5.7 & 0.1 & 0.4 & 0.67 & 0.04 & 8.7 & 3.8 & 26.0 \\
\hline 48 & LUT & 8.98 & 8.02 & 1.48 & 4.0 & n.d. & 31.4 & 0.1 & 1.0 & 0.69 & 0.05 & 4.3 & 5.1 & 12.5 \\
\hline 49 & HAG & 4.35 & 7.76 & 2.19 & 0.8 & 1.4 & 8.6 & 0.4 & 1.0 & 1.11 & 0.27 & 56.5 & 8.2 & 100.4 \\
\hline 50 & GRD & 9.20 & 8.00 & 2.83 & 2.5 & 12.9 & 65.7 & 0.1 & 0.8 & 1.32 & 0.14 & 100.9 & 25.6 & 49.8 \\
\hline 51 & SCE & 9.90 & 8.40 & 1.98 & 0.5 & 22.1 & 217.1 & 0.1 & 0.5 & 0.79 & 0.47 & 27.4 & 15.6 & 56.9 \\
\hline 52 & OBE & 0.70 & 7.65 & 3.06 & 1.8 & 8.6 & 71.4 & 0.3 & 2.0 & 0.96 & 0.87 & 48.7 & 28.9 & 305.3 \\
\hline 53 & TÜR & 0.70 & 7.48 & 3.98 & 3.3 & 23.6 & 102.9 & 0.1 & 3.1 & 1.48 & 0.71 & 250.4 & 38.1 & 69.4 \\
\hline 54 & SWL & 9.90 & 8.67 & 1.57 & 2.0 & 12.1 & 57.1 & 0.1 & 0.4 & 0.70 & 0.06 & 7.8 & 7.4 & 24.9 \\
\hline 55 & BIC & 2.50 & 7.30 & 5.42 & 7.8 & 14.3 & 234.3 & 0.1 & 2.4 & 1.32 & 0.73 & 111.3 & 33.5 & 69.0 \\
\hline 56 & EGE & 0.30 & 7.25 & 4.72 & 5.4 & 3.6 & 280.0 & 0.1 & 2.3 & 2.23 & 0.32 & 54.3 & 27.4 & 172.6 \\
\hline 57 & DIT & 0.50 & 7.48 & 6.20 & 8.2 & 155.0 & 260.0 & 0.3 & 2.2 & 2.75 & 0.31 & 236.5 & 81.3 & 124.9 \\
\hline 58 & INK & 11.40 & 8.08 & 4.58 & 5.2 & 207.9 & 308.6 & 0.4 & 2.0 & 2.70 & 0.38 & 257.4 & 67.0 & 113.5 \\
\hline 59 & HAS & 10.50 & 8.08 & 5.88 & 4.9 & 428.6 & 491.4 & 0.1 & 1.1 & 2.79 & 0.84 & 196.5 & 52.7 & 35.2 \\
\hline 60 & NUS & 5.80 & 7.84 & 5.36 & 5.7 & 212.9 & 348.6 & 0.1 & 1.1 & 2.17 & 0.83 & 202.6 & 73.9 & 46.6 \\
\hline 61 & GAW & 10.10 & 8.14 & 4.32 & 3.7 & 43.6 & 97.1 & 0.2 & 0.7 & 2.00 & 0.39 & 105.7 & 10.7 & 122.1 \\
\hline 62 & HÜN & 10.70 & 8.22 & 4.24 & 4.9 & 76.4 & 162.9 & 0.2 & 1.7 & 2.03 & 0.33 & 339.6 & 62.4 & 39.9 \\
\hline 63 & ROU & 8.60 & 8.20 & 3.18 & 2.6 & 7.9 & 51.4 & 0.1 & 0.6 & 1.40 & 0.05 & 185.7 & 13.6 & 14.6 \\
\hline 64 & $\mathrm{ABB}$ & 7.20 & 7.95 & 2.69 & 3.4 & 4.3 & 40.0 & 0.1 & 0.8 & 1.13 & 0.05 & 112.2 & 15.3 & 10.7 \\
\hline 65 & MON & 10.50 & 8.06 & 1.86 & 4.1 & 13.6 & 77.1 & 0.1 & 0.5 & 0.71 & 0.13 & 110.0 & 25.6 & 6.4 \\
\hline 66 & SEG & 4.60 & 7.60 & 3.01 & 2.7 & 62.1 & 171.4 & 0.5 & 1.2 & 1.18 & 0.20 & 104.8 & 14.3 & 82.9 \\
\hline 67 & END & 4.40 & 7.53 & 3.71 & 2.4 & 8.6 & 125.7 & 0.3 & 1.3 & 1.40 & 0.49 & 114.8 & 25.3 & 74.4 \\
\hline 68 & LIO & 7.00 & 8.15 & 1.95 & 1.1 & 7.1 & 16.4 & 0.2 & 0.4 & 0.91 & 0.12 & 16.5 & 16.1 & 45.9 \\
\hline
\end{tabular}


Appendix III: Chemical analysis of sediments, and land use

\begin{tabular}{|c|c|c|c|c|c|c|c|c|c|c|c|c|c|c|c|}
\hline no & Abb. & $\begin{array}{l}\mathrm{TN} \\
\mathrm{mg} / \mathrm{g}\end{array}$ & $\begin{array}{l}\mathrm{C}_{\mathrm{tot}} \\
\mathrm{mg} / \mathrm{g}\end{array}$ & $\begin{array}{l}\mathrm{C}_{\text {inorg }} \\
\mathrm{mg} / \mathrm{g}\end{array}$ & $\begin{array}{l}\mathrm{C}_{\text {org }} \\
\mathrm{mg} / \mathrm{g}\end{array}$ & $\begin{array}{l}\mathrm{CaCO}_{3} \\
\%\end{array}$ & $\begin{array}{l}\mathrm{Ca} \\
\mathrm{mg} / \mathrm{g}\end{array}$ & $\begin{array}{l}\mathrm{Mg} \\
\mathrm{mg} / \mathrm{g}\end{array}$ & $\begin{array}{l}\mathrm{Na} \\
\mathrm{mg} / \mathrm{g}\end{array}$ & $\begin{array}{l}\mathrm{K} \\
\mathrm{mg} / \mathrm{g}\end{array}$ & agric. & urban & bare & wooded & green \\
\hline 1 & MUZ & 20.5 & 178.3 & 5.1 & 173.1 & 4.3 & 23.4 & 9.3 & 0.3 & 4.0 & 0.29 & 0.50 & 0.00 & 0.17 & 0.04 \\
\hline 2 & ORI & 10.4 & 119.1 & 0.7 & 118.3 & 0.6 & 4.1 & 4.1 & 0.2 & 5.9 & 0.05 & 0.14 & 0.01 & 0.79 & 0.01 \\
\hline 3 & BUR & 5.9 & 117.0 & 52.0 & 65.0 & 43.3 & 180.2 & 5.3 & 0.2 & 2.6 & 0.61 & 0.10 & 0.01 & 0.26 & 0.03 \\
\hline 4 & $\mathrm{MOO}$ & 4.2 & 94.3 & 50.9 & 43.5 & 42.4 & 170.7 & 6.9 & 0.3 & 3.8 & 0.66 & 0.09 & 0.02 & 0.22 & 0.01 \\
\hline 5 & LOC & 4.5 & 126.3 & 80.8 & 45.4 & 67.4 & 256.2 & 4.1 & 0.2 & 2.2 & 0.61 & 0.03 & 0.00 & 0.33 & 0.03 \\
\hline 6 & SEE & 7.0 & 123.8 & 59.9 & 63.9 & 49.9 & 204.4 & 5.6 & 0.4 & 2.8 & 0.77 & 0.07 & 0.00 & 0.15 & 0.01 \\
\hline 7 & GER & 5.8 & 145.1 & 88.6 & 56.5 & 73.8 & 293.9 & 1.2 & 0.1 & 0.7 & 0.78 & 0.15 & 0.00 & 0.05 & 0.02 \\
\hline 8 & UEB & 6.0 & 143.2 & 80.7 & 62.5 & 67.3 & 263.4 & 0.4 & 0.1 & 1.1 & 0.80 & 0.05 & 0.06 & 0.06 & 0.02 \\
\hline 9 & LÜT & 8.3 & 132.9 & 48.9 & 83.9 & 40.8 & 164.6 & 9.8 & 0.1 & 2.7 & 0.67 & 0.07 & 0.07 & 0.10 & 0.09 \\
\hline 10 & WIL & 9.3 & 149.1 & 44.6 & 104.5 & 37.2 & 155.7 & 6.2 & 0.3 & 3.9 & 0.90 & 0.01 & 0.05 & 0.04 & 0.00 \\
\hline 11 & HÜT & 4.7 & 127.8 & 86.5 & 41.3 & 72.1 & 282.8 & 5.0 & 0.1 & 1.1 & 0.68 & 0.03 & 0.03 & 0.25 & 0.00 \\
\hline 12 & HUS & 5.8 & 141.0 & 87.3 & 53.7 & 72.8 & 294.2 & 2.0 & 0.1 & 0.4 & 0.33 & 0.04 & 0.05 & 0.54 & 0.04 \\
\hline 13 & MET & 5.4 & 127.3 & 73.9 & 53.4 & 61.5 & 245.3 & 3.7 & 0.2 & 1.0 & 0.45 & 0.26 & 0.04 & 0.20 & 0.06 \\
\hline 14 & CHA & 10.5 & 173.5 & 75.4 & 98.1 & 62.8 & 255.8 & 4.8 & 0.1 & 0.8 & 0.25 & 0.10 & 0.12 & 0.45 & 0.08 \\
\hline 15 & SOP & 6.6 & 142.5 & 75.6 & 66.9 & 63.0 & 263.7 & 2.1 & 0.1 & 1.2 & 0.81 & 0.05 & 0.02 & 0.12 & 0.00 \\
\hline 16 & BUG & 8.2 & 155.0 & 58.0 & 97.0 & 48.3 & 187.7 & 3.6 & 0.1 & 2.4 & 0.32 & 0.08 & 0.04 & 0.51 & 0.05 \\
\hline 17 & BLA & 1.8 & 88.5 & 69.4 & 19.1 & 57.8 & 207.0 & 11.7 & 0.3 & 3.1 & 0.00 & 0.01 & 0.00 & 0.89 & 0.10 \\
\hline 18 & $\mathrm{SCH}$ & 3.4 & 54.2 & 21.9 & 32.3 & 18.3 & 78.1 & 13.2 & 0.2 & 9.5 & 0.53 & 0.02 & 0.07 & 0.27 & 0.11 \\
\hline 19 & ROT & 8.4 & 131.7 & 54.7 & 77.0 & 45.6 & 193.9 & 5.2 & 0.2 & 2.6 & 0.36 & 0.35 & 0.00 & 0.19 & 0.10 \\
\hline 20 & MAU & 5.1 & 124.9 & 80.6 & 44.2 & 67.2 & 292.3 & 4.0 & 0.3 & 1.8 & 0.77 & 0.08 & 0.02 & 0.12 & 0.01 \\
\hline 21 & SEL & 5.6 & 87.0 & 26.2 & 60.8 & 21.8 & 104.2 & 2.3 & 0.1 & 2.8 & 0.46 & 0.04 & 0.04 & 0.46 & 0.00 \\
\hline 22 & BRE & 4.8 & 136.3 & 89.1 & 47.2 & 74.3 & 334.4 & 1.4 & 0.1 & 1.1 & 0.32 & 0.07 & 0.02 & 0.56 & 0.03 \\
\hline 23 & TAI & 11.0 & 142.1 & 34.7 & 107.3 & 28.9 & 139.2 & 4.6 & 0.1 & 4.2 & 0.45 & 0.02 & 0.00 & 0.53 & 0.00 \\
\hline 24 & SCW & 17.6 & 186.4 & 3.1 & 183.3 & 2.6 & 23.8 & 2.6 & 0.2 & 3.1 & 0.48 & 0.01 & 0.07 & 0.37 & 0.06 \\
\hline 25 & VOR & 3.0 & 51.3 & 21.4 & 29.9 & 17.8 & 80.3 & 7.4 & 0.3 & 6.4 & 0.50 & 0.01 & 0.12 & 0.28 & 0.09 \\
\hline 26 & TSC & 0.6 & 80.1 & 71.1 & 9.0 & 59.2 & 218.2 & 9.3 & 0.5 & 3.5 & 0.26 & 0.01 & 0.57 & 0.10 & 0.06 \\
\hline 27 & $\mathrm{CHV}$ & 5.4 & 51.4 & 0.7 & 50.7 & 0.6 & 7.8 & 4.8 & 0.7 & 5.6 & 0.27 & 0.01 & 0.01 & 0.67 & 0.04 \\
\hline 28 & RET & 4.9 & 50.5 & 13.2 & 37.3 & 11.0 & 45.6 & 5.8 & 0.3 & 7.6 & 0.45 & 0.05 & 0.09 & 0.10 & 0.32 \\
\hline 29 & FÄL & 6.4 & 66.8 & 10.9 & 55.9 & 9.1 & 50.7 & 6.7 & 0.2 & 9.7 & 0.45 & 0.00 & 0.29 & 0.05 & 0.21 \\
\hline 30 & SAL & 5.2 & 71.0 & 21.4 & 49.6 & 17.8 & 85.1 & 7.7 & 0.5 & 9.1 & 0.52 & 0.00 & 0.29 & 0.03 & 0.15 \\
\hline 31 & GRO & 2.7 & 48.8 & 22.1 & 26.7 & 18.4 & 45.5 & 41.2 & 0.6 & 7.9 & 0.79 & 0.01 & 0.03 & 0.15 & 0.02 \\
\hline 32 & ENG & 2.0 & 68.6 & 44.7 & 23.9 & 37.3 & 149.2 & 4.6 & 0.5 & 2.5 & 0.29 & 0.00 & 0.59 & 0.04 & 0.08 \\
\hline 33 & SEB & 21.8 & 185.6 & 1.2 & 184.4 & 1.0 & 14.8 & 8.7 & 0.2 & 3.4 & 0.42 & 0.00 & 0.15 & 0.15 & 0.27 \\
\hline 34 & TAN & 6.8 & 96.1 & 0.5 & 95.6 & 0.4 & 6.5 & 7.0 & 0.3 & 4.8 & 0.70 & 0.02 & 0.18 & 0.00 & 0.10 \\
\hline 35 & MEL & 2.8 & 29.7 & 1.2 & 28.4 & 1.0 & 5.8 & 9.0 & 0.5 & 6.2 & 0.72 & 0.01 & 0.19 & 0.02 & 0.06 \\
\hline 36 & SEW & 6.7 & 59.5 & 0.4 & 59.1 & 0.3 & 4.0 & 3.9 & 0.1 & 8.5 & 0.24 & 0.00 & 0.00 & 0.70 & 0.06 \\
\hline 37 & BRT & 5.1 & 84.1 & 41.6 & 42.5 & 34.7 & 139.0 & 9.2 & 0.1 & 4.2 & 0.83 & 0.05 & 0.00 & 0.10 & 0.01 \\
\hline 38 & TAY & 7.2 & 106.3 & 46.5 & 59.9 & 38.7 & 164.0 & 3.1 & 0.1 & 4.8 & 0.35 & 0.01 & 0.21 & 0.25 & 0.17 \\
\hline 39 & NER & 7.2 & 73.9 & 13.9 & 60.0 & 11.6 & 54.5 & 10.7 & 0.2 & 8.1 & 0.44 & 0.00 & 0.08 & 0.30 & 0.18 \\
\hline 40 & SÄG & 2.4 & 53.8 & 37.9 & 15.9 & 31.6 & 123.1 & 8.0 & 1.0 & 5.7 & 0.41 & 0.00 & 0.40 & 0.02 & 0.17 \\
\hline 41 & WAN & 2.8 & 26.4 & 0.2 & 26.1 & 0.2 & 7.0 & 8.4 & 0.2 & 5.9 & 0.03 & 0.00 & 0.84 & 0.00 & 0.13 \\
\hline 42 & BAN & 3.3 & 35.5 & 6.7 & 28.8 & 5.6 & 26.4 & 15.5 & 0.7 & 5.2 & 0.32 & 0.00 & 0.58 & 0.02 & 0.07 \\
\hline 43 & IFF & 1.4 & 44.4 & 34.0 & 10.4 & 28.3 & 115.1 & 8.1 & 0.4 & 5.1 & 0.18 & 0.00 & 0.73 & 0.00 & 0.09 \\
\hline 44 & FLU & 2.2 & 35.2 & 18.1 & 17.1 & 15.1 & 56.4 & 8.0 & 0.6 & 5.6 & 0.08 & 0.00 & 0.92 & 0.00 & 0.00 \\
\hline 45 & LÄM & 1.7 & 56.9 & 44.5 & 12.4 & 37.1 & 147.7 & 7.7 & 0.7 & 5.2 & 0.30 & 0.00 & 0.53 & 0.00 & 0.17 \\
\hline 46 & TRÜ & 1.6 & 59.6 & 44.6 & 15.0 & 37.2 & 147.3 & 5.4 & 0.3 & 2.6 & 0.31 & 0.00 & 0.61 & 0.05 & 0.03 \\
\hline 47 & $\mathrm{BAC}$ & 2.1 & 19.1 & 2.2 & 16.9 & 1.9 & 11.6 & 4.5 & 0.5 & 3.8 & 0.46 & 0.00 & 0.46 & 0.00 & 0.09 \\
\hline 48 & LUT & 8.4 & 63.9 & 0.4 & 63.6 & 0.3 & 6.6 & 7.3 & 0.7 & 6.6 & 0.56 & 0.00 & 0.25 & 0.05 & 0.14 \\
\hline 49 & HAG & 7.9 & 77.3 & 0.3 & 77.1 & 0.2 & 7.9 & 4.9 & 0.4 & 5.6 & 0.42 & 0.00 & 0.55 & 0.00 & 0.03 \\
\hline 50 & GRD & 4.4 & 47.2 & 4.8 & 42.4 & 4.0 & 21.0 & 12.3 & 0.3 & 2.6 & 0.49 & 0.22 & 0.01 & 0.26 & 0.02 \\
\hline 51 & SCE & 2.7 & 74.7 & 51.7 & 23.0 & 43.1 & 91.2 & 63.6 & 0.3 & 4.0 & 0.26 & 0.00 & 0.58 & 0.00 & 0.16 \\
\hline 52 & OBE & 7.7 & 64.6 & 6.4 & 58.2 & 5.3 & 24.7 & 39.0 & 0.2 & 4.2 & 0.63 & 0.06 & 0.02 & 0.26 & 0.03 \\
\hline 53 & TÜR & 6.1 & 102.7 & 59.0 & 43.7 & 49.1 & 192.1 & 11.7 & 0.2 & 3.3 & 0.58 & 0.15 & 0.00 & 0.25 & 0.02 \\
\hline 54 & SWL & 4.1 & 80.3 & 48.4 & 31.9 & 40.3 & 153.6 & 16.2 & 0.5 & 3.0 & 0.27 & 0.00 & 0.57 & 0.01 & 0.15 \\
\hline 55 & BIC & 3.5 & 91.4 & 56.8 & 34.6 & 47.3 & 167.1 & 39.3 & 0.1 & 3.3 & 0.28 & 0.03 & 0.00 & 0.69 & 0.00 \\
\hline 56 & EGE & 13.9 & 158.6 & 34.2 & 124.3 & 28.5 & 137.4 & 5.5 & 0.1 & 1.7 & 0.00 & 0.00 & 0.03 & 0.80 & 0.17 \\
\hline 57 & DIT & 12.5 & 165.4 & 60.7 & 104.8 & 50.5 & 205.4 & 2.3 & 0.2 & 1.4 & 0.69 & 0.06 & 0.03 & 0.21 & 0.00 \\
\hline 58 & INK & 9.8 & 132.8 & 47.8 & 85.0 & 39.8 & 164.5 & 8.9 & 0.2 & 2.8 & 0.68 & 0.09 & 0.01 & 0.21 & 0.01 \\
\hline 59 & HAS & 4.7 & 130.7 & 92.9 & 37.8 & 77.4 & 295.7 & 7.6 & 0.1 & 1.0 & 0.76 & 0.05 & 0.00 & 0.17 & 0.01 \\
\hline 60 & NUS & 6.1 & 141.5 & 86.5 & 54.9 & 72.1 & 277.3 & 8.8 & 0.1 & 1.0 & 0.69 & 0.07 & 0.01 & 0.24 & 0.00 \\
\hline 61 & GAW & 7.5 & 121.7 & 57.4 & 64.3 & 47.8 & 185.0 & 13.0 & 0.1 & 2.5 & 0.27 & 0.02 & 0.00 & 0.71 & 0.00 \\
\hline 62 & HÜN & 7.7 & 145.1 & 68.0 & 77.1 & 56.7 & 225.4 & 6.6 & 0.1 & 1.8 & 0.82 & 0.09 & 0.01 & 0.06 & 0.02 \\
\hline 63 & ROU & 10.2 & 169.6 & 60.6 & 109.0 & 50.5 & 206.4 & 5.1 & 0.1 & 2.2 & 0.40 & 0.10 & 0.00 & 0.50 & 0.00 \\
\hline 64 & ABB & 23.1 & 218.3 & 24.4 & 193.9 & 20.4 & 88.0 & 6.4 & 0.1 & 2.5 & 0.50 & 0.10 & 0.00 & 0.40 & 0.00 \\
\hline 65 & MON & 25.2 & 203.0 & 0.5 & 202.5 & 0.4 & 9.9 & 13.4 & 0.2 & 2.3 & 0.49 & 0.15 & 0.01 & 0.34 & 0.01 \\
\hline 66 & SEG & 12.1 & 131.6 & 35.4 & 96.2 & 29.5 & 120.3 & 11.2 & 0.1 & 2.4 & 0.25 & 0.08 & 0.05 & 0.61 & 0.01 \\
\hline 67 & END & 5.6 & 117.9 & 70.4 & 47.5 & 58.7 & 231.9 & 10.3 & 0.1 & 3.0 & 0.40 & 0.10 & 0.00 & 0.50 & 0.01 \\
\hline 68 & LIO & 9.2 & 87.0 & 5.5 & 81.5 & 4.6 & 28.2 & 10.0 & 0.0 & 6.4 & 0.30 & 0.01 & 0.28 & 0.14 & 0.27 \\
\hline
\end{tabular}

